OPEN ACCESS

Edited by:

Florence Abram,

National University of Ireland Galway

Ireland

Reviewed by:

Alyson E. Santoro,

University of California, Santa Barbara,

United States

Katharina Kujala

University of Oulu, Finland

*Correspondence:

Clara A. Fuchsman

cfuchsm1@u.washington.edu

Gabrielle Rocap

rocap@u.washington.edu

Specialty section:

This article was submitted to

Aquatic Microbiology,

a section of the journal

Frontiers in Microbiology

Received: 15 August 2017 Accepted: 20 November 2017 Published: 05 December 2017

Citation:

Fuchsman CA, Devol AH,

Saunders JK, McKay $C$ and Rocap G (2017) Niche Partitioning of the $N$

Cycling Microbial Community of an Offshore Oxygen Deficient Zone.

Front. Microbiol. 8:2384.

doi: 10.3389/fmicb.2017.02384

\section{Niche Partitioning of the N Cycling Microbial Community of an Offshore Oxygen Deficient Zone}

\author{
Clara A. Fuchsman*, Allan H. Devol, Jaclyn K. Saunders, Cedar McKay and \\ Gabrielle Rocap*
}

School of Oceanography, University of Washington, Seattle, WA, United States

Microbial communities in marine oxygen deficient zones (ODZs) are responsible for up to half of marine $\mathrm{N}$ loss through conversion of nutrients to $\mathrm{N}_{2} \mathrm{O}$ and $\mathrm{N}_{2}$. This $\mathrm{N}$ loss is accomplished by a consortium of diverse microbes, many of which remain uncultured. Here, we characterize genes for all steps in the anoxic $\mathrm{N}$ cycle in metagenomes from the water column and $>30 \mu \mathrm{m}$ particles from the Eastern Tropical North Pacific (ETNP) ODZ. We use an approach that allows for both phylogenetic identification and semi-quantitative assessment of gene abundances from individual organisms, and place these results in context of chemical measurements and rate data from the same location. Denitrification genes were enriched in $>30 \mu \mathrm{m}$ particles, even in the oxycline, while anammox bacteria were not abundant on particles. Many steps in denitrification were encoded by multiple phylotypes with different distributions. Notably three $\mathrm{N}_{2} \mathrm{O}$ reductases (nosZ), each with no cultured relative, inhabited distinct niches; one was free-living, one dominant on particles and one had a $\mathrm{C}$ terminal extension found in autotrophic S-oxidizing bacteria. At some depths $>30 \%$ of the community possessed nitrite reductase nirK. A nirK OTU linked to SAR11 explained much of this abundance. The only bacterial gene found for NO reduction to $\mathrm{N}_{2} \mathrm{O}$ in the ODZ was a form of qnorB related to the previously postulated "nitric oxide dismutase," hypothesized to produce $\mathrm{N}_{2}$ directly while oxidizing methane. However, similar qnorB-like genes are also found in the published genomes of many bacteria that do not oxidize methane, and here the qnorB-like genes did not correlate with the presence of methane oxidation genes. Correlations with $\mathrm{N}_{2} \mathrm{O}$ concentrations indicate that these qnorB-like genes likely facilitate $\mathrm{NO}$ reduction to $\mathrm{N}_{2} \mathrm{O}$ in the ODZ. In the oxycline, qnorB-like genes were not detected in the water column, and estimated $\mathrm{N}_{2} \mathrm{O}$ production rates from ammonia oxidation were insufficient to support the observed oxycline $\mathrm{N}_{2} \mathrm{O}$ maximum. However, both qnorB-like and nos $\mathrm{Z}$ genes were present within particles in the oxycline, suggesting a particulate source of $\mathrm{N}_{2} \mathrm{O}$ and $\mathrm{N}_{2}$. Together, our analyses provide a holistic view of the diverse players in the low oxygen nitrogen cycle.

Keywords: denitrification, anammox, Eastern Tropical North Pacific, oxygen minimum zone, particles 


\section{INTRODUCTION}

Naturally occurring oxygen deficient zones (ODZs), defined here as water containing $<10 \mathrm{nM}$ oxygen, constitute $<1 \%$ of the ocean volume, but contribute $30-50 \%$ of $\mathrm{N}$ loss from the marine system through $\mathrm{N}_{2}$ production (DeVries et al., 2013). In the absence of oxygen, microbes in these waters use a variety of different terminal electron acceptors, including oxidized nitrogen (nitrate and nitrite), resulting in the production of both $\mathrm{N}_{2}$ and the greenhouse gas $\mathrm{N}_{2} \mathrm{O}$. Due to the temperature-dependent solubility of oxygen, concentrations are predicted to be further reduced in the future, increasing the size of ODZs (Deutsch et al., 2011) with implications for increased $\mathrm{N}_{2}$ production and consequent $\mathrm{N}$ limitation of global primary production. Thus, understanding the microbial community responsible for $\mathrm{N}_{2}$ production is important to predicting the nitrogen budget of a changing ocean.

Denitrification and anammox are the two known pathways for $\mathrm{N}_{2}$ production. Denitrification is the multi-step reduction of $\mathrm{NO}_{3}^{-}$to $\mathrm{N}_{2}$ paired with oxidization of organic matter, reduced sulfur, or methane. Nitrate is reduced through four reduction steps, each encoded by a different enzyme. However, not all denitrifying organisms possess all the enzymes needed to reduce $\mathrm{NO}_{3}^{-}$all the way to $\mathrm{N}_{2}$. Many encode genes for only a subset of the steps and rely on other microbes for the production or consumption of their reactants and products (Zumft, 1997). This separation of individual reactions may be possible because most steps in denitrification occur in the periplasm (Zumft, 1997), which should ease transport of reactants and products across the outer membrane. Genes in the denitrification pathway are found widespread throughout the microbial tree of life (Zumft, 1997). Some horizontal gene transfer of denitrification genes has occurred and some denitrification genes have even been found on plasmids (Zumft, 1997). However, duplication and divergence of genes followed by incomplete lineage sorting maybe more important than horizontal gene transfer in accounting for the diversity of denitrification genes (Jones et al., 2008). Denitrifiers are also metabolically diverse, with heterotrophic denitrifiers coupling $\mathrm{N}$ reduction with organic matter oxidation and autotrophic denitrifiers coupling $\mathrm{N}$ reduction with sulfur or methane oxidation to fuel carbon fixation (Hannig et al., 2007; Ettwig et al., 2010; Babbin et al., 2014). In contrast, autotrophic bacteria in the order Brocadiales in the Planctomycetes phylum are the other organisms known to carry out the anammox process, which involves reduction of $\mathrm{NO}_{2}^{-}$with $\mathrm{NH}_{4}^{+}$to produce $\mathrm{N}_{2}$. The process occurs in an internal compartment where the membrane is composed of ladderane lipids; these tightly fitting lipids are needed to isolate the toxic intermediate hydrazine $\left(\mathrm{N}_{2} \mathrm{H}_{4}\right)$ from the rest of the cell and prevent hydrazine leakage, which would make anammox energetically unfeasible (Sinninghe Damsté et al., 2002). This complex cellular structure may be one reason why anammox is restricted phylogenetically, with Scalindua the only genera of anammox bacteria thus far found in the marine environment (van de Vossenberg et al., 2013).

The relative importance of anammox compared to denitrification in marine $\mathrm{N}_{2}$ production is still unclear (Lam et al., 2009; Ward et al., 2009; Dalsgaard et al., 2012). If the breakdown of organic matter by heterotrophic denitrifiers is the source of ammonia to anammox, then stoichiometrically heterotrophic denitrification should contribute $70 \%$ and anammox $30 \%$ to $\mathrm{N}_{2}$ production (Devol, 2003) though the consumption of nitrite through nitrite oxidation can shift this ratio to $>40 \%$ anammox (Penn et al., 2016). However, in older studies, denitrifiers, identified molecularly by targetting the nitrite reductase gene nirS were in low abundance (Lam et al., 2009, 2011; Jensen et al., 2011; Jayakumar et al., 2013; Kalvelage et al., 2013) and had low diversity (Bowen et al., 2015). More recently, using primer-independent approaches the copper-dependent nitrite reductase encoded by nirK was found in addition to nirS, and was more abundant (Ganesh et al., 2014, 2015; Glass et al., 2015; Lüke et al., 2016). In the Arabian Sea and ETSP, this nirK was predominantly from ammonia oxidizing archaea while in the ETNP nirK from nitrite oxidizer Nitrospina was found in addition (Glass et al., 2015; Lüke et al., 2016). However, neither ammonia oxidizing archaea or nitrite oxidizing bacteria are complete denitrifiers, so the role of nirK in $\mathrm{N}_{2}$ production is still unclear.

Anammox and denitrifying bacteria may have different niches in the ODZ. Size fractionated studies in the ETSP and the Black Sea indicate that marine anammox bacteria are primarily free-living (Fuchsman et al., 2012b; Ganesh et al., 2014, 2015) as are nitrate reducers (Ganesh et al., 2015), but the last two steps in the denitrification pathway are enriched in $>1.6 \mu \mathrm{m}$ suspended particles (Ganesh et al., 2014, 2015). The most abundant nitrate reducer in the ETNP was a free-living SAR11 in the ODZ which has two different nitrate reductases transferred from quite distinct bacteria (gammaproteobacteria and candidate phyla OP1) but lacks genes for the last two steps in denitrification (Tsementzi et al., 2016). The organisms containing genes for the last step in denitrification, $\mathrm{N}_{2} \mathrm{O}$ reductase nos $Z$, are largely unknown (Ganesh et al., 2014, 2015). The addition of sterilized sediment trap material significantly increased denitrification and anammox rates in all three marine ODZs (Babbin et al., 2014; Chang et al., 2014). Denitrification rates increase more than anammox (Babbin et al., 2014; Chang et al., 2014), probably because denitrification uses organic matter directly while anammox uses ammonia from organic matter degradation. $\mathrm{N}_{2}$ production has also been found inside particles composed of diatom aggregates or zooplankton carcasses at hypoxic oxygen concentrations (Stief et al., 2016, 2017).

Denitrification in marine ODZs is generally attributed to heterotrophic denitrification. However, some autotrophic denitrification has been measured in incubations with sulfide in the coastal ETSP (Canfield et al., 2010) and autotrophic $\mathrm{N}_{2}$ production by methane oxidizers has been proposed in the ETNP (Padilla et al., 2016). Cand. Methylomirabilis oxyfera, isolated from fresh water, can oxidize methane with nitrite, forming $\mathrm{N}_{2}$ from nitrite without an $\mathrm{N}_{2} \mathrm{O}$ intermediate (Ettwig et al., 2010). The gene in question was dubbed nitric oxide dismutase (nod) based on in silico analysis (Ettwig et al., 2012) and has been found in both transcript and gene data from the ETNP (Padilla et al., 2016). However, rates of methane oxidation in the ETNP ODZ are the slowest rates measured in the ocean $\left(0.034-15 \times 10^{-3}\right.$ 
nmol $\mathrm{CH}_{4} \mathrm{~L}^{-1} \mathrm{~d}^{-1}$ ), suggesting that methane oxidation is not a dominant process in the ETNP (Pack et al., 2015).

Nitrite and ammonium oxidation have been shown previously in the upper ODZ in the ETNP (Peng et al., 2015; Garcia-Robledo et al., 2017). Although the ETNP ODZ contains $<10 \mathrm{nM}$ oxygen (Tiano et al., 2014), the low oxygen $\mathrm{K}_{\mathrm{m}}$ for nitrite oxidation $0.5 \pm 4 \mathrm{nM}$ (Bristow et al., 2016), indicates nitrite oxidation is possible when oxygen concentrations below detection. Oxygen needed for nitrite oxidation may be provided by photosynthesis by Prochlorococcus in the upper ODZ or by mixing of waters from the oxycline above (Peters et al., 2016; Garcia-Robledo et al., 2017). The $K_{m}$ for ammonia oxidizers is $333 \pm 130 \mathrm{nM}$, which is significantly higher than for nitrite oxidation (Bristow et al., 2016). Correspondingly, ammonia oxidation rates drop off more rapidly than nitrite oxidation rates in the upper ODZ (Peng et al., 2015).

Here, we take a holistic approach to the low oxygen nitrogen cycle using metagenomics combined with existing chemical and rate measurements. We performed a phylogenetic analysis of key functional genes in the $\mathrm{N}$ cycle from assemblies of a metagenomic 10 -depth profile in the water column and the $>30 \mu \mathrm{m}$ particle attached community at three key depths in the offshore ETNP ODZ. We identified previously unknown phylotypes for many key $\mathrm{N}$ cycling genes. We then used a read placement approach to quantify the distributions of all phylotypes for each gene in a semi-quantitative manner and found multiple differences both with respect to depth and presence in the particle attached vs. whole water community.

\section{METHODS}

\section{Hydrographic Data}

Samples were collected in April 2012 aboard the R/V Thompson TN278 using $10 \mathrm{~L}$ Niskin bottles on a 24 bottle CTD-rosette. A Seabird 911 Conductivity Temperature Density meter, a Seabird SBE 43 Dissolved Oxygen Sensor, a WETLabs ECO Chlorophyll Fluorometer, and a Biospherical/Licor PAR/Irradiance Sensor were attached to the rosette. Nutrient samples were filtered (GF/F glass fiber; nominal pore size $0.7 \mu \mathrm{m}$ ) before analysis. Nutrient analyses were performed by members of the University of Washington Marine Chemistry Laboratory on board the ship using a Technicon AAII system as described by the World Ocean Circulation Experiment (WOCE) Hydrographic Program protocol (Gordon et al., 1995). Ammonium was measured on board the ship using the fluorometric orthophthaldialdehyde (OPA) method due to the low detection limit (10 nM) of this method (Holmes et al., 1999). Hydrographic and nutrient data from the cruise are deposited at http://data. nodc.noaa.gov/accession/0109846. Eight day averaged satellite chlorophyll (April 7, 2012) from satellite MODIS Aqua R2014 was downloaded from http://www.science.oregonstate. edu/ocean.productivity.

\section{$\mathrm{N}_{2}$ Gas Concentrations}

$\mathrm{N}_{2}$ gas samples were collected from St 136 and analyzed as in Chang et al. (2010, 2012). Very briefly, duplicate gas samples were collected in evacuated $185 \mathrm{~mL}$ glass flasks sealed with a Louwers-Hapert valve and containing dried mercuric chloride as a preservative. To prevent air contamination when sampling, samples were transferred from the Niskin bottle to the sample flask under a local $\mathrm{CO}_{2}$ atmosphere. Head-space gases were cryogenically processed to completely remove $\mathrm{CO}_{2}$ and residual water vapor and run through an inline $\mathrm{CuO}$ furnace to remove oxygen. Then gases were measured at the Stable Isotope Lab, School of Oceanography, University of Washington on a Finnigan Delta XL isotope ratio mass spectrometer. The anoxic samples were measured against a standard containing zero oxygen. Background $\mathrm{N}_{2}$ /Ar ratios from representative water outside the ODZ were removed as in Chang et al. (2012), leaving concentrations of biologically produced $\mathrm{N}_{2}$.

\section{Metagenomic Data}

DNA samples were obtained from station $136\left(106.543^{\circ} \mathrm{W}\right.$ $17.043^{\circ} \mathrm{N}$; cast 136) at 10 depths including the oxycline and anoxic zones. Two liters of Niskin water were vacuum filtered onto a $0.2 \mu \mathrm{m}$ SUPOR filter. At station BB2, a nearby station $\left(107.148^{\circ} \mathrm{W} 16.527^{\circ} \mathrm{N}\right.$; cast 141$), \sim 4 \mathrm{~L}$ were prefiltered through $>30 \mu \mathrm{m}$ filters at 100,120 , and $150 \mathrm{~m}$ depths and subsequently filtered onto $0.2 \mu \mathrm{m}$ SUPOR filters. $>30 \mu \mathrm{m}$ filters were sequenced for all three depths, but only the $<30 \mu \mathrm{m}$ filter from $120 \mathrm{~m}$ was sequenced. Particles $>30 \mu \mathrm{m}$ should be composed of sinking as well as large suspended particles (Clegg and Whitfield, 1990). Station 136 and BB2 were only $83 \mathrm{~km}$ apart and hydrographic conditions were very similar (Figures S1, S2). DNA was extracted from filters using freeze thaw followed by incubation with lysozyme and proteinase $\mathrm{K}$ and phenol/chloroform extraction. A Rubicon THRUPLEX kit was used for library prep using $50 \mathrm{ng}$ of DNA per sample. Four libraries were sequenced on an Illumina HiSeq 2500 in rapid mode ( $\sim 25$ million 150 bp paired-end reads per sample) at Michigan State. The other 10 libraries were sequenced on an Illumina HiSeq 2500 in high output mode ( 40-70 million 125 bp paired-end reads per sample) at the University of Utah (Table S1). Sequences were quality checked, trimmed, and remaining adapter sequences were removed using Trimmomatic (Bolger et al., 2014). Paired reads that overlapped were combined with Flash (Magoc and Salzberg, 2011).

Metagenomic sequences from each sample were assembled independently into larger contigs. For de novo assembly we pre-processed reads with the khmer software package (Crusoe et al., 2015), first using normalize-by-median which implements a Digital normalization algorithm (Brown et al., 2012) to reduce high coverage reads to 20x coverage, followed by filter-abund.py to trim reads of kmers with an abundance below 2, and finally we used filter-below-abund.py to trim kmers with counts above 50 (Zhang et al., 2015). We assembled the khmer processed reads with the VELVET (1.2.10) assembler (Zerbino, 2010), using a kmer size of 45 . The N50, or median length, for assembled contigs ranged between 1,300 and 1,800 bp in the anoxic zone, with $\sim 30 \%$ of reads assembled (Table S1). The Prokka annotation pipeline (Seemann, 2014) was used for gene calling, which relies on the Prodigal algorithm for identification of coding sequence coordinates on the contigs (Hyatt et al., 2010), and preliminary functional annotation identified through similarity searching 
with BLAST (Altschul et al., 1997) against UniProt (Apweiler et al., 2004) and RefSeq (Pruitt et al., 2007) databases and with HMMER v. 3.1 (Eddy, 2011) against protein domain databases Pfam (Punta et al., 2012) and TIGRFAMs (Haft et al., 2013). ETNP 2012 metagenomic reads and assembled contigs can be found at NCBI GenBank bioproject PRJNA350692.

For each gene of interest, a maximum likelihood amino acid phylogenetic tree was constructed using published full-length gene sequences as well as full or nearly full-length sequences assembled from the metagenomes themselves. Rather than rely on Prokka annotations, potential gene sequences of interest were identified from the metagenome assemblies by searching a custom blast database (Altschul et al., 1997) of all our assembled open reading frames as called by Prodigal, using representative published sequences from each section of the phylogenetic tree as query sequences. All sequences with an e-value cut-off of $<-60$ were included in the phylogenetic tree for further identification. Assembled genes with Ns were removed. In addition, full-length published gene sequences of closely related genes to the gene of interest were included to act as outgroups in the trees. All assembled sequences recruited from blast were combined with the previously published full-length gene sequences and aligned in amino acid space with MUSCLE v. 3.8.1551 (Edgar, 2004). Maximum likelihood phylogenetic trees were constructed with the reference sequence alignments of the genes of interest using the program RAxML v. 8.1.20 (Stamatakis, 2014). In this process, sequences with exactly identical amino acid sequences were deduplicated (Stamatakis, 2014). The trees were constructed with a gamma model of rate heterogeneity, and appropriate amino acid substitution models were determined for each tree, and bootstrap analyses $(n=100)$ were performed.

A phylogenetic placement approach was used to characterize short metagenomic reads related to the targeted genes of interest (Berger et al., 2011) in a semi-quantitative and phylogenetically specific manner (Saunders and Rocap, 2016). For read placement, the short metagenomic reads were recruited via tblastn search of the metagenomes using an e-value cut-off of $<-5$ (Altschul et al., 1997). The recruited reads were trimmed to the edge of the gene of interest to remove any overhang of up or downstream sequence, trimmed to the proper reading frame of the blast results, and converted to amino acid space. Any sequence ambiguities and stop codons were removed. Presence of sequence ambiguities and stop codons were negligible. Only sequences longer than $100 \mathrm{bp}$ (33 amino acids) after quality trimming were used for placement analysis. These amino acid translated reads were aligned to the reference sequences in amino acid space using PaPaRa: Parsimony-based Phylogeny-Aware Read Alignment program v. 2.5 (Berger and Stamatakis, 2011). Following the PaPaRa alignment, paired end reads were combined into one sequence in the same alignment using a python script and placed as one read on the tree using the EPA: Evolutionary Placement Algorithm portion of RAxML (Stamatakis, 2014). Reads that placed with outgroups on each phylogenetic tree were not counted toward that gene's total. This was particularly important for closely related genes such as nitrate reductase $n a r G$, with the $n \times r A$ outgroup and for nitrite oxidoreductase $n x r B$ with the $n a r H$ outgroup.
To take into account differences in sequencing effort between samples and recruitment capacity among the different genes, read placement length normalized occurrence of the target genes were normalized to the length normalized abundance of the universal single copy core gene RNA polymerase ( $r p o B$; Figure S3).

$$
\% \text { prokaryotic community }=\frac{\frac{\text { Gene A reads }}{\text { Length } A}}{\frac{r p o B \text { reads }}{\text { Length rpoB }}} .
$$

Since RNA polymerase is, to our knowledge, present as a single copy gene in all bacterial and archaeal genomes, normalization of a target gene occurrence to RNA polymerase abundance indicates what percentage of the prokaryotic community contains the gene of interest. This normalization allows our placements to be quantitative in a relative manner. However, this analysis does not take into account that the density of prokaryotic cells may, and undoubtedly do, change with depth.

Several papers have been published from this cruise, and we compare our metagenomic data to previous rate, qPCR, and lipid data. For clarification, these data and their references are listed in Table S2.

\section{Previously Published Transcripts}

In order to assess whether phylotypes observed in our metagenomes were expressed in the environment, we applied the same read placement approach to previously published metatranscriptomic data. Transcripts from 2 size fractions $(0.2-$ 1.6 and $1.6-30 \mu \mathrm{m})$ at five low oxygen depths from a coastal station in the ETNP in $2013\left(18^{\circ} 54.0^{\prime} \mathrm{N}, 104^{\circ} 54.0^{\prime} \mathrm{W}\right.$ ) (Ganesh et al., 2015) were placed on our phylogenetic trees using methods as above. Transcript libraries had $\sim 120,000$ reads per sample.

\section{RESULTS AND DISCUSSION}

We occupied 2 stations in the offshore Eastern Tropical North Pacific in April 2012. At these stations, the depth of anoxia was $\sim 105 \mathrm{~m}$ according to oxygen measurements with a STOX sensor (detection limit $2 \pm 5 \mathrm{nM} \mathrm{O}_{2}$; Tiano et al., 2014). The oxycline, where oxygen concentrations decrease rapidly, extended from 60 to $100 \mathrm{~m}$ (Figure 1A). STOX oxygen concentrations were 4.7 and $0.8 \mu \mathrm{M}$ at 90 and $100 \mathrm{~m}$ in the lower oxycline (Tiano et al., 2014). Ammonium concentrations, as determined by the extremely sensitive OPA method, were undetectable in the anoxic zone (Figure 1C), but the nitrite maximum reached nearly $5 \mu \mathrm{M}$ at $150 \mathrm{~m}$ (Figure 1C). $\mathrm{N}_{2} \mathrm{O}$ concentrations had the usual large maximum in the oxycline, but also had a second smaller maximum at $140-150 \mathrm{~m}$ in the anoxic zone (Figure 1F; Peng et al., 2015). Biological $\mathrm{N}_{2}$ gas increased in the anoxic zone and was between 10 and $11 \mu \mathrm{M}$ (Figure 1H). To characterize the functional and taxonomic diversity of this oligotrophic ODZ community, we constructed and sequenced metagenomes from whole water from 10 depths $(60-300 \mathrm{~m})$ at station 136 and from $>30 \mu \mathrm{m}$ particles collected from Niskin bottles at 3 depths at station BB2, which was close to and very similar physiochemically to station 136 (Figure S2). We classified short read sequences by both function 


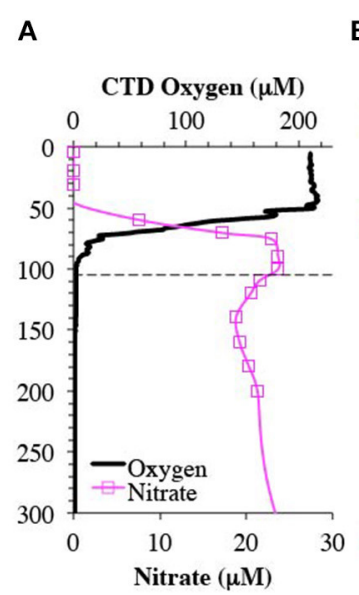

B

E
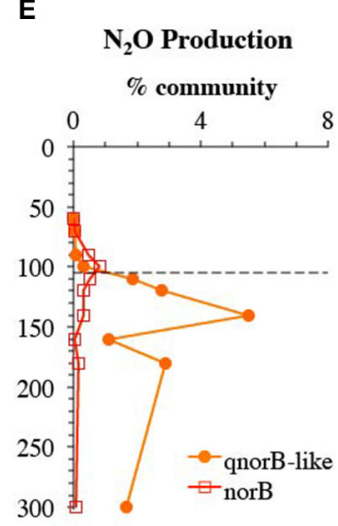

Nitrate reduction
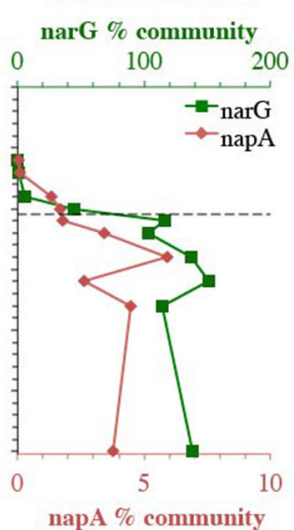

$\mathbf{F}$

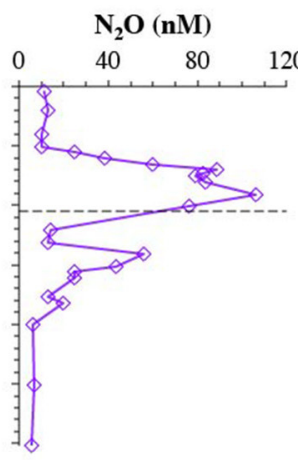

C
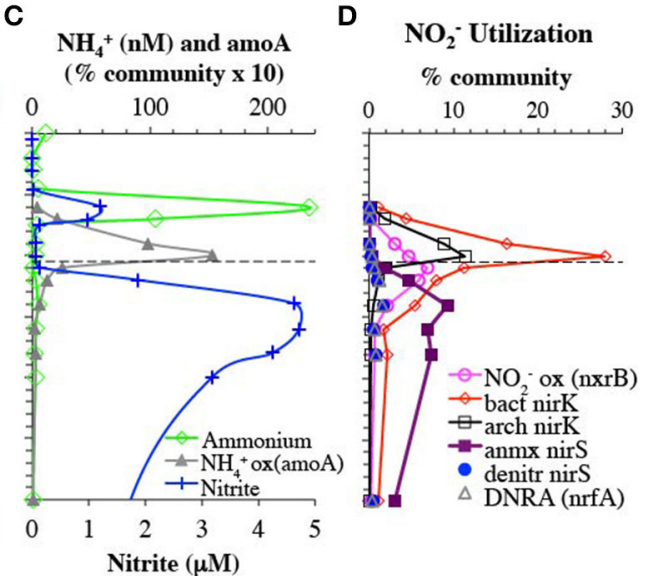

G

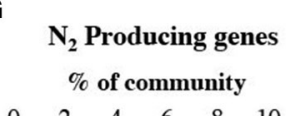

H

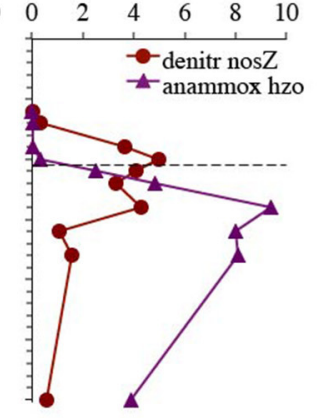

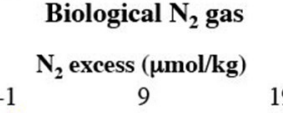

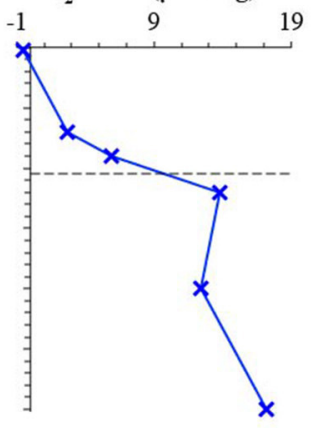

FIGURE 1 | Depth profiles of metagenomic reads encoding for enzymes used in the low oxygen $\mathrm{N}$ cycle and relevant chemical species. (A) CTD oxygen and nitrate concentrations from St 136. (B) Genes used in nitrate reduction. Genes for nitrate reductases narG and napA are shown on different axes for clarity. (C) Nitrite and OPA ammonium concentrations from St 136 as well as the gene for ammonia monooxygenase (amoA) used in ammonia oxidation. (D) Genes used for nitrite utilization: nitrite reduction to $\mathrm{NO}$ (bacterial and archaea nirk, anammox nirS, and bacterial nirS), nitrite reduction to ammonium (DNRA: nrfA) and nitrite oxidation (nxrB). (E) $\mathrm{N}_{2} \mathrm{O}$ producing genes: $\mathrm{NO}$ reductases norB and qnorB-like. (F) $\mathrm{N}_{2} \mathrm{O}$ concentration profile from St BB2 (Peng et al., 2015). (G) $\mathrm{N}_{2}$ producing genes: $\mathrm{N}_{2} \mathrm{O}$ reductase (nosZ) represents denitrification and hydrazine oxidoreductase (hzo) represents anammox. (H) Biological $\mathrm{N}_{2}$ gas from St 136. Dashed line represents the top of the ODZ, which is at $105 \mathrm{~m}$ (Tiano et al., 2014). \% Community is calculated in comparison to the single copy core gene RNA polymerase (rpoB).

and phylotype by placing reads on reference trees constructed from full length genes, including those assembled from our metagenomes.

\section{Community Structure of Free Living and Particle Communities}

We examined community structure using the RNA polymerase $(r p o B)$ gene, found in all archaeal and bacterial genomes (Figure 2, Figure S3). SAR11 was the most abundant clade overall, making up $60 \%$ of the community at $300 \mathrm{~m}$. SAR 11 has previously been found to be $10-40 \%$ of the community in ODZs (Tsementzi et al., 2016). Other notable heterotrophic clades present included SAR406, SAR116, Marine Group II euryarchaeota, and Flavobacteria (Figure 2). Autotrophic microbes present included Cyanobacteria (photosynthesis), Marine Group I Thaumarchaeota (ammonia oxidation), Nitrospina (nitrite oxidation), and Cand. Scalindua (anammox), and together they made up $<20 \%$ of the community in the oxycline and anoxic water column (Figure 2). Autotrophic $S$ oxidizers are also known to be active in ODZs (Stewart et al., 2012), but known S oxidizers, including SUP05, were not identified here. However, it should be noted that a large number of the $r p o B$ sequences were novel phylotypes including novel clades of Actinobacteria, Chloroflexi, Acidobacteria, and gammaproteobacteria whose metabolic lifestyles are unknown (Figure S3).

Particles may be hotspots of heterotrophic activity in the ocean and harbor a microbial community distinct from those free-living in the water column (Delong et al., 1993; Ploug et al., 1999). To further examine the microbial community on particles that make up the sinking organic matter in the ODZ, we sequenced metagenomes from $>30 \mu \mathrm{m}$ particles collected from Niskin bottles at 3 depths at the offshore station BB2. Particles $>30 \mu \mathrm{m}$ should be composed of sinking as well as large suspended particles (Clegg and Whitfield, 1990). Estimates of $16 \mathrm{~S}$ rRNA abundance in the ETNP using qPCR indicated that 8-15 


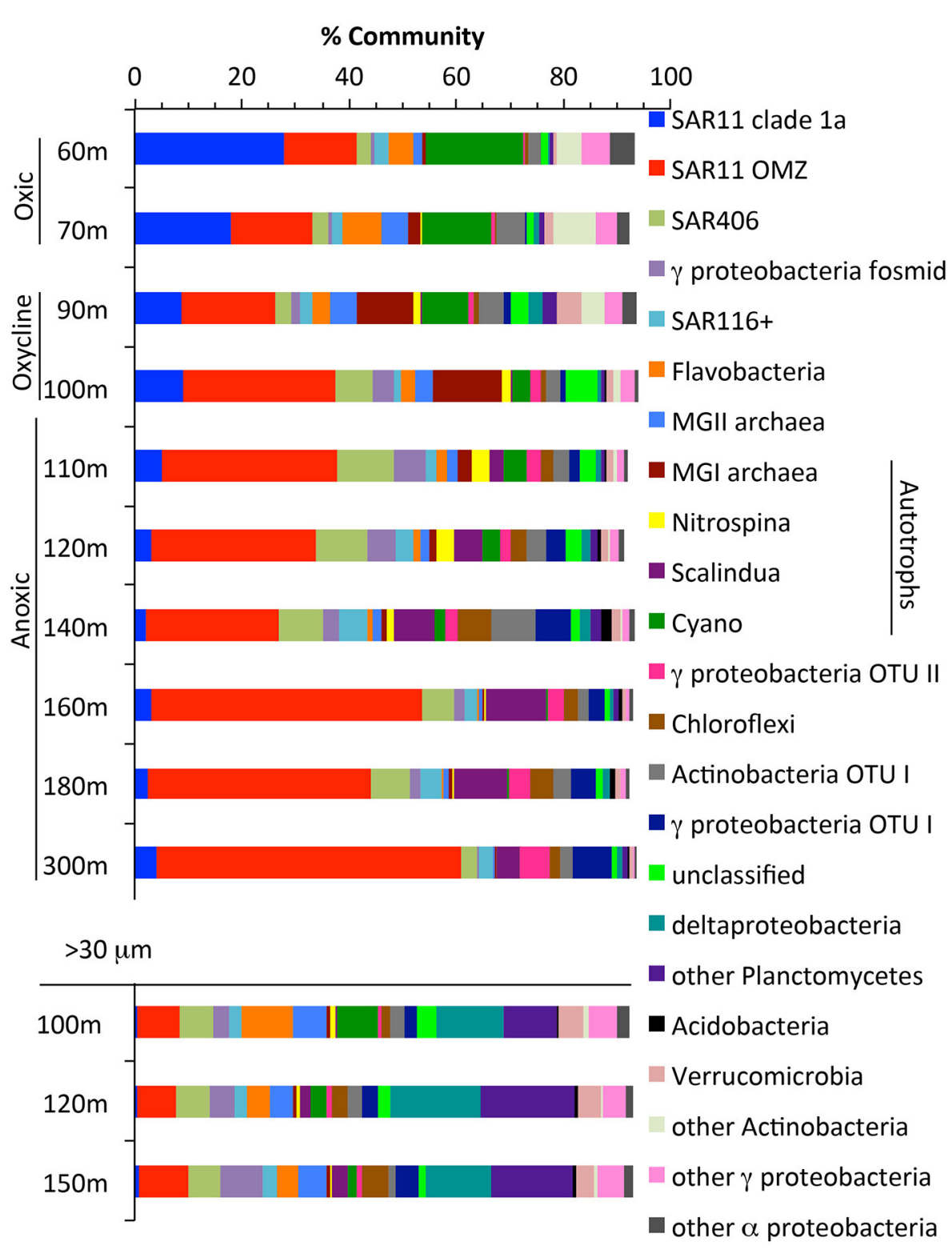

FIGURE 2 | The community in the water column and in > 30 micron particles as determined by RNA polymerase gene rpoB. Groups found on the rpoB phylogenetic tree (Figure S2). Known autotrophs are labeled in the legend. Gamma fosmid represents relatives of HOT fosmid GU567967, a heterotrophic Salinisphaeraceae.

times more $16 \mathrm{~S}$ rRNA was found per $\mathrm{mL}$ in free-living $(<1.6 \mu \mathrm{m})$ communities compared to particle $(>1.6 \mu \mathrm{m})$ fractions (Ganesh et al., 2015). Thus, the free-living community likely dominates bulk water samples. In our dataset, the microbial community on particles $(>30 \mu \mathrm{m})$ differed from the community in the bulk water (Figure 2). Among others, SAR11, Marine Group I archaea (ammonia oxidizing) and Cand. Scalindua (anammox), all known to be free-living (Fuchsman et al., 2011, 2012b, Ganesh et al., 2014, 2015), were a much smaller proportion of the particle community. Delta proteobacteria, Planctomycetes, Flavobacteria, Verrucomicrobia, and MGII euryarchaeota were enriched in particles, consistent with observations in other environments (Delong et al., 1993; Fuchsman et al., 2011, 2012b; Ganesh et al.,
2014; Glass et al., 2015; Orsi et al., 2015). In contrast to previous observations in the ETNP (Ganesh et al., 2015), the nitriteoxidizer Nitrospina was not enriched in particles. This could be due to the different size filter used to define "particles" (1.6 vs. $30 \mu \mathrm{m}$ used here) because individual Nitrospina cells can be $6 \mu \mathrm{m}$ long (Spieck and Bock, 2015).

\section{Genetic Capacity for Denitrification Enhanced on Particles}

To examine the role of sinking and large suspended particles in production of $\mathrm{N}_{2}$ by the ODZ microbial community, we mapped metagenomic reads onto reference phylogenetic trees constructed for key genes in the anoxic N cycle (Figure 3). 


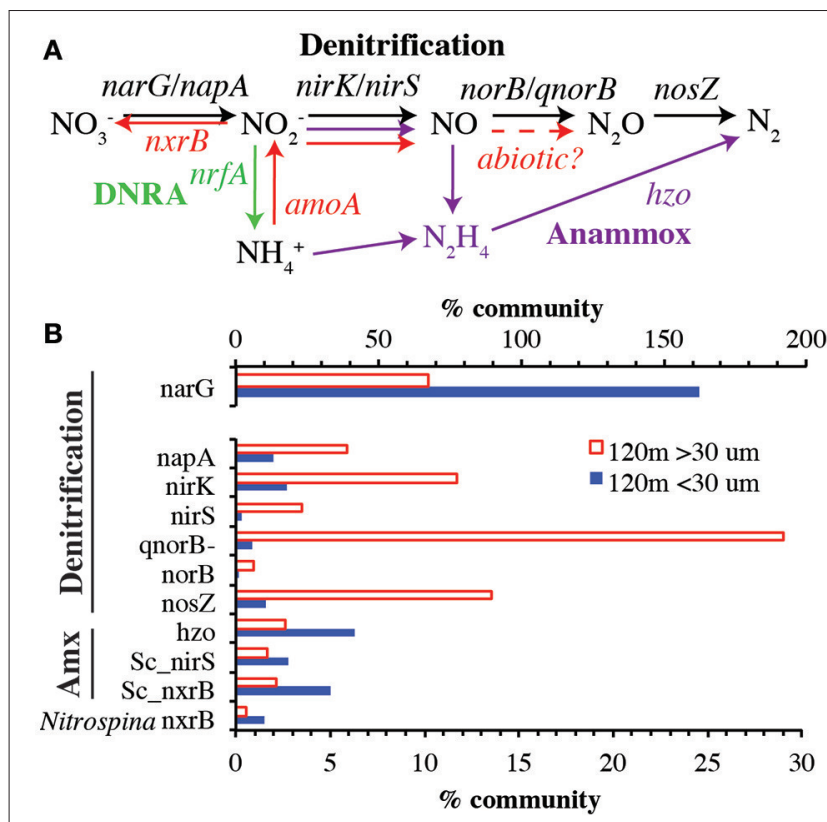

FIGURE 3 | (A) The low oxygen N cycle with genes examined in this paper indicated. Black arrows indicate denitrification. Purple arrows indicate anammox. Red arrows indicate processes mediated by ammonia and nitrite oxidizing organisms. (B) Comparison of genes between $>30 \mu \mathrm{m}$ and $<30 \mu \mathrm{m}$ fractions at $120 \mathrm{~m}$. Note that nitrate reduction gene narG is on its own axis. amo $A$ and $n r f A$ were $<1 \%$ of community at $120 \mathrm{~m}$, so are not shown. Sc_nirS and Sc_nxrB indicate genes belonging to anammox bacteria Cand. Scalindua. Nitrospina $n \times r B$ represents nitrite oxidizing bacteria. \% Community is calculated in comparison to the single copy core gene RNA polymerase (rpoB). nitrite-oxidizer Nitrospina was more abundant in the $<30 \mu \mathrm{m}$ fraction.

\section{Gene Depth Profiles}

We next examined the depth distribution and taxonomic diversity of these same key genes (Figure 3A) in the oxycline and upper $200 \mathrm{~m}$ of the ODZ water column. We compare these depth profiles to measurements of chemical species that serve as reactants and products for the reactions catalyzed by the enzymes these genes encode (Figure 1).

\section{Nitrification Genes}

The ammonia monooxygenase (amoA) gene for ammoniaoxidizing archaea had a maximum of $15 \%$ of community at $100 \mathrm{~m}$ at the bottom of the oxycline (Figure 1C). This maximum in amo $A$ was below the primary maxima in ammonium and nitrite concentrations found at $60 \mathrm{~m}$. This depth profile combined with ammonia oxidation rates from Peng et al. (2015) indicate that nitrite is being produced in the $80-100 \mathrm{~m}$ region, despite the lack of measurable nitrite in this region. The gene encoding the nitrite oxidizing enzyme nitrite oxidoreductase $(n x r B)$ is unmeasurable at $70 \mathrm{~m}$, but $3 \%$ of the community at $90 \mathrm{~m}$, and had a maximum of $7 \%$ of the community in the ODZ at $110 \mathrm{~m}$ that can be solely attributed to Nitrospina (Figure 1D, Figure S6). The presence of Nitrospina $n \times r B$ in the upper ODZ is consistent with $n \times r B$ transcript data from the ETNP (Garcia-Robledo et al., 2017). The presence of Nitrospina may help explain the lack of measurable nitrite in the $80-100 \mathrm{~m}$ region.

\section{Nitrate Reduction}

The first step in denitrification, nitrate reduction to nitrite, can be carried out by nitrate reductases encoded by either narG or napA, both of which were detected here. However, narG was an order of magnitude more abundant than all the other denitrification genes (Figure 1B). The narG maximum at $160 \mathrm{~m}$ corresponded with a reduction in nitrate concentrations and the secondary nitrite maximum (Figures 1A-C), implying nitrate reduction activity. Again, after normalizing with the single copy core gene, more than $100 \%$ of the community contained the narG, implying multiple copies per genome in some bacteria. SAR11, which is very abundant in our $r p o B$ data (Figure 2), is known to have two distinct narG in the same cell (Tsementzi et al., 2016) and we found both SAR11 narG types here along with six other phylotypes (Figure 4). If we assume that all SAR11 genomes have 2 types of narG, we calculate that $75-105 \%$ of the total microbial community has narG. This number may suggest that other groups in addition to SAR11 also possess duplicate copies of narG. In contrast, the two phylotypes of napA totaled only $5 \%$ of the community in the ODZ (Figure 1B, Figure S4). The capacity for nitrate reduction is clearly prevalent in the community. Examination of selected long contigs containing narG indicated multiple nitrate reductase subunits and at least one nitrate transporter ( $\operatorname{ar} U$, narT, or narK) in all cases (Figure S5). Contigs associated with OTU I contained a transposase, indicating the potential for horizontal gene transfer (Figure S5). 

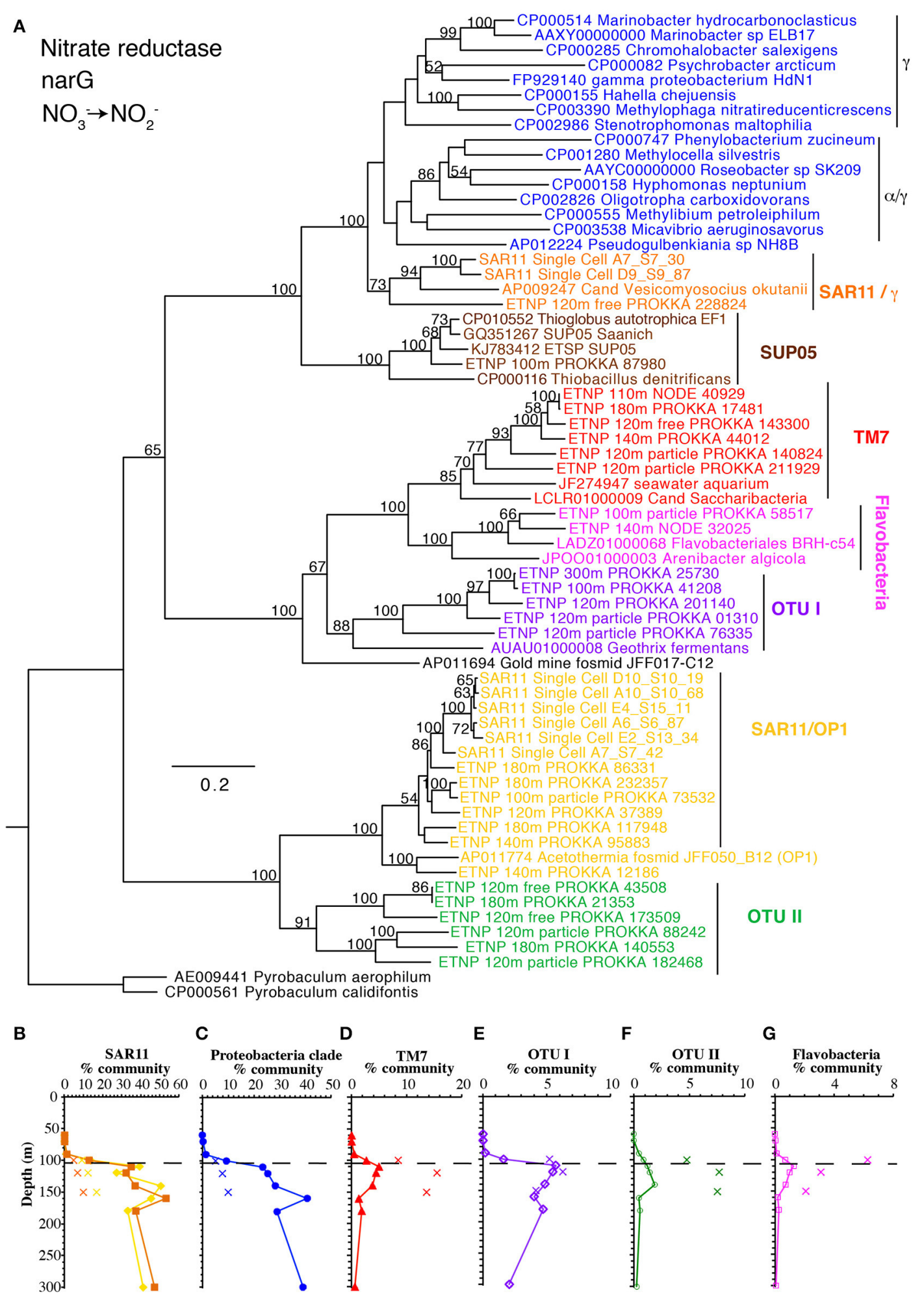

FIGURE 4 | (A) Phylogenetic tree of membrane bound nitrate reductase gene narG. Names with ETNP indicate sequences assembled from our metagenomic samples. Labels and colors on the tree match phylotype depth profiles (B-G). (B) Depth profile of both forms of narG belonging to SAR11. (C) Combined profile of $\alpha$ and $\gamma$ proteobacteria, (D) uncultured group TM7, (E) unknown OTU I, (F) unknown OTU II, and (G) Flavobacteria. In all depth profiles, Xs indicate particulate (>30 $\mu$ m) samples. Dashed line indicated the top of the ODZ. \% Community is calculated in comparison to the single copy core gene RNA polymerase (rpoB). 


\section{Nitrite Reduction}

The nitrite produced by nitrate reduction can have many fates, including further reduction to NO, oxidation back to nitrate, and reduction to ammonia. We found evidence for existence of all of these pathways, in differing amounts. As mentioned previously, the gene encoding the nitrite oxidizing enzyme nitrite oxidoreductase $(n x r B)$ had a maximum in the upper ODZ (Figure 1D). In contrast $n r f A$, encoding the DNRA nitrite reductase to ammonia, was present but always $<2 \%$ of the community (Figure 1D). Only one phylotype of $n r f A$ was present (Figure S7).

The second step in denitrification, nitrite reduction to NO, was dominated by nirK (copper containing nitrite reductase) although nirs (iron containing nitrite reductase) was also detected in much lower abundances (Figure 1D). nirK had a maximum at the top of the ODZ at $100 \mathrm{~m}$, where it was possessed by $\sim 30 \%$ of the community (Figure 1D). At least 10 phylotypes were detected and five were present in $>1 \%$ of the community (Figure 5). Three of these phylotypes, (OTU I, Chloroflexi, and MGI thaumarchaeota) had a maximum in the lower oxycline and were undetectable below $140 \mathrm{~m}$ (Figures 5B,D,E), while the nirK from nitrite oxidizer Nitrospina had maxima within the ODZ at $110 \mathrm{~m}$ (Figure 5F). Only one nirK phylotype (OTU II) was clearly particle attached and this phylotype also had a maximum in the ODZ (Figure 5C). OTU II nirK was found on an assembled contig with a nos $Z$ gene (Figure 6), which is discussed with that nos $Z$ phylotype below. We note that unlike previous metagenomic examination of nirK (Glass et al., 2015; Lüke et al., 2016), MGI Thaumarchaeota were not the dominant nirK containing organism. Instead bacterial OTU I was $21 \%$ of the community at $100 \mathrm{~m}$ (Figure 5). Since transcripts from the 2013 ETNP cruise examined in Glass et al. (2015) place on our OTU I nirK, it seems this difference between reports may be methodological rather than due to interannual variability. Unfortunately, assemblies of OTU I nirK from our study were short contigs. However, a published SAR11 metagenomic contig from the coastal ETNP contained a partial nirK (scaffold 00818) (Tsementzi et al., 2016). This partial SAR11 nirK sequence was too short (242 bp) to be a branch on our phylogenetic tree, but aligned with $98.6 \%$ identity to the OTU I cluster here using MUSCLE (Edgar, 2004). The published representative of cluster OTU I on our phylogenic tree is from a fosmid obtained Station ALOHA (HF0770-09N23) which also appears to be a SAR11 relative (best BLAST hit for the fosmid using the nt database: SAR11 relative CP003809 HIMB5, E-value: 0.0). Presence in some SAR11 bacteria would explain how OTU I of nirK could be so abundant (Figure 5B). While nirK was more abundant on particles than in the water column at $120 \mathrm{~m}$ (Figure 3), at $100 \mathrm{~m}$, nirK was more abundant in bulk water $(26 \%)$ at station 136 than on particles (11\%) at BB2, (Figure S8). This difference is due to the dominance of SAR11 nirK OTU I in the water column at the top of the ODZ and is consistent with the free-living nature of SAR11 determined from $r p o B$ (Figure 2).

Although nirS was present in a much lower percentage of the community than nirK, at least five distinct phylotypes were still present (Figure S9). With the exception of anammox nirS
(Figure 1D), the other 4 phylotypes were present in $<2 \%$ of the community, and all had maxima within the ODZ at $140 \mathrm{~m}$. Two of these phylotypes (OTU II and III) were particle-attached (Figure S9). The prevalence of the nirK copper nitrite reductase over nirS is consistent with other untargeted approaches that have also detected nirK (Ganesh et al., 2014, 2015; Glass et al., 2015; Lüke et al., 2016) in ODZs but it is at odds with prior primer-based approaches that indicated nirK was not environmentally relevant in ODZs (Jayakumar et al., 2013).

\section{Nitric Oxide Reduction}

The third step in denitrification, $\mathrm{NO}$ reduction to $\mathrm{N}_{2} \mathrm{O}$, is mediated by nitric oxide reductase, encoded by genes nor $B$ or qnorB (Lam et al., 2011). However, the canonical forms of these genes were present in very low abundance in this water column $(<0.9 \%$ norB; Figure 1). Instead most of our assembled sequences and short read sequences cluster (Figure 7) with a form of the qnorB suggested by in silico analysis to be nod (nitric oxide dismutase) in the methane-utilizing denitrifier Cand. Methylomirabilis from the NC10 phylum, which was theorized to reduce $\mathrm{NO}$ straight to $\mathrm{N}_{2}$ without a $\mathrm{N}_{2} \mathrm{O}$ intermediate (Ettwig et al., 2012). However, our data is not consistent with all of the genes detected here encoding a nitric oxide dismutase. Many bacteria that have qnorB genes in this cluster are not known to dismutate nitric oxide and some also contain nitrous oxide reductase in their genomes (Figure 7). The qnorB-like gene has a maximum at $140 \mathrm{~m}$ at the same depth as the second $\mathrm{N}_{2} \mathrm{O}$ peak (Figures 1E,F) where $\mathrm{N}_{2} \mathrm{O}$ production rates are modeled to have a maximum (Babbin et al., 2015). However, neither norB nor qnorB was present at these depths (Figure 1). Theoretically, NO released from a cell could abiotically or nonenzymatically produce $\mathrm{N}_{2} \mathrm{O}$ with iron or thiols under anoxic conditions (Hughes, 2008; Kampschreur et al., 2011; Kozlowski et al., 2016), but this has not been shown in the environment. Thus, if the qnorB-like gene is not involved in $\mathrm{N}_{2} \mathrm{O}$ production, there are no known genes present to produce $\mathrm{N}_{2} \mathrm{O}$ in the ODZ. Though we can't rule out the presence of an unknown novel gene for $\mathrm{N}_{2} \mathrm{O}$ production, it would have to be in a completely different gene family from norB/qnorB/qnorB-like to be missed by our methods. When the quinol binding site and active site of qnor, qnor-like, putative nod, and ETNP assembled contigs are compared, the quinol binding site appears to have more variability between gene types than the active site (Figure S10). While our assembled ETNP sequences do share the differences in the active site seen in the putative nod enzyme, these changes are also seen in the other qnorB-like genes (Figure S10). We suggest that at least some, potentially all, of the qnorB-like phylotypes detected here retain their function as nitric oxide reductases like their homologs nor $B$ and qnorB.

Sequences for nod-like/qnorB-like genes from metatranscript assemblies in the coastal ETNP were combined with NC10 16S rRNA sequences related to Cand. Methylomirabilis as evidence to suggest a role for methane oxidation in $\mathrm{N}_{2}$ production in ODZs (Padilla et al., 2016). The transcripts from the 2013 cruise place on our tree at OTUs II, III, and IV (Figure 7) and assembled sequences from Padilla et al. (2016) belong to 


\section{A}

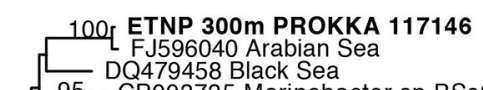

DQ479458 Black Sea

70 [ NC 00795 Shewanella denitrificans OS217

WP041509912 Shewanella sp cp20

$100 \mid$ ETNP $140 \mathrm{~m}$ PROKKA 03828

\begin{tabular}{ll|l}
58 & OTU II
\end{tabular}

z乙 $\leftarrow$ KJ498264 wastewater

FJ596074 Arabian Sea

62 T FJ596091 Arabian Sea

- EU91085 Uncultured bacterium 1042 soil

798- NC003047 Sinorhizobium melilotit 1021

74- AY078253 Ochrobactrum sp 4FB14

EU910855 Uncultured bacterium 1062 soil

98- WP0 17521516 Pseudomonas nitroreducens

AGI26810 Pseudomonas denitrificans

88- ETNP 180m PROKKA 73732
$100^{\circ}$ AFIBO 1000033 SAR324 SCGC AAAO01-C10
AFIA0100237 SAR324 SCGC AAA240-J09

AFIA01000237 SAR324 SCGC_AAA

6100 FJ596083 Arabiaian Sea

FJ596062 Arabian Sea

62 99- ETNP 120m PROKKA 91044

DQ D479538 Black Sea

50- EU795282 fosmid HF0770-09N23 HOT

50 C ETNP $100 \mathrm{~m}$ PROKKA 02901

85 . ETNP $90 \mathrm{~m}$ PROKKA 56022

_ ETNP 90m PROKKA 56022
ETNP $100 \mathrm{~m}$ NODE 604427

WP063301204 Pseudovibrio sp WM33

74 FJ596090 Arabian Sea

94- DQ479705 Black Sea

ф2 - FJ596055 Arabian Sea 19972

WP046008138 Oleispira antarctica

\section{OTU I}

\section{Nitrite reductase nirk \\ $\mathrm{NO}_{2}^{-} \rightarrow \mathrm{NO}$}

롲

\section{SAR324}

$78-$ GAP62154 Ardenticatena maritima

$78 \longrightarrow$ WPO21031782 Salinisphaera shabanensis

100 K ETNP $100 \mathrm{~m}$ NODE 1210862

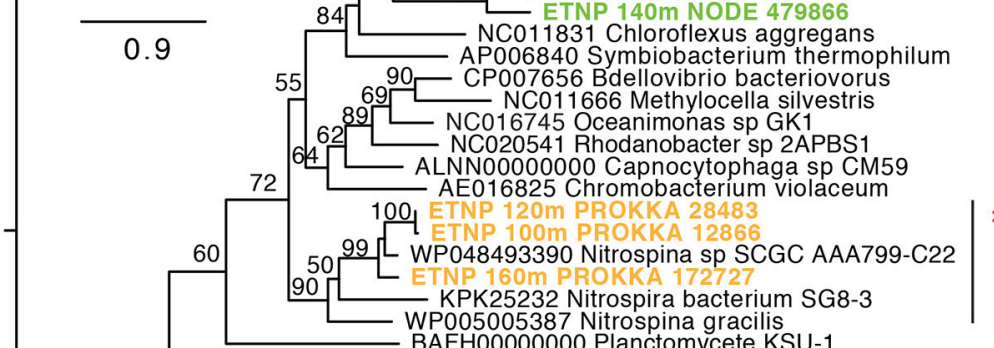

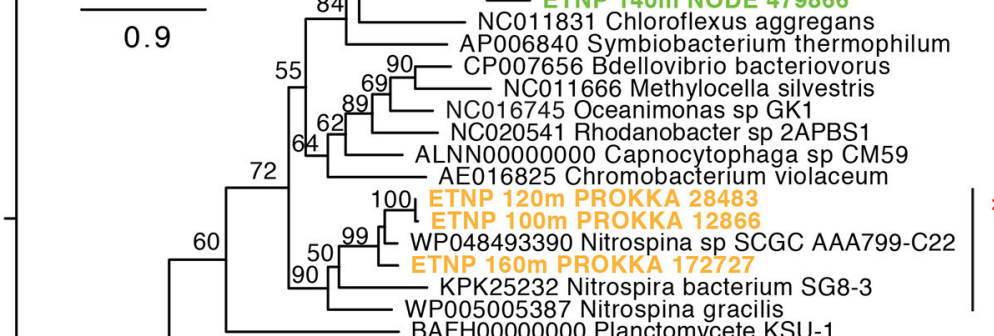

87

BAFH00000000 Planctio gracilis
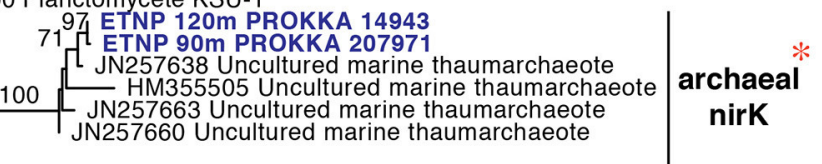

$\stackrel{20}{3}$

Nitrospina

F Archaeal nirK G Nitrospina nirK

B

Total nirK

C nirk OTU I D

nirK OTU II
$\%$ community

E Chloroflexi nirk $\%$ community

$\%$ community

$\begin{array}{llllllllllllllllll}0 & 10 & 20 & 30 & 40 & 0 & 5 & 10 & 15 & 20 & 25 & 0 & 2 & 4 & 6 & 0 & 2 & 4\end{array}$
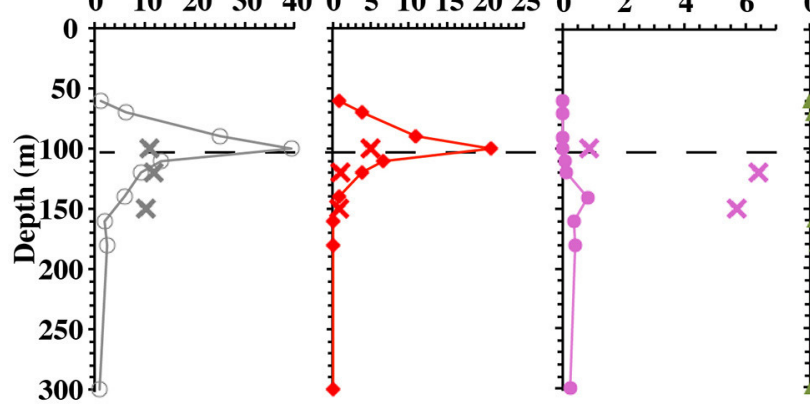

40

$\begin{array}{lllllllll}0 & 2 & 4 & 6 & 8 & 1012 & 0\end{array}$

$\begin{array}{llllll}0 & 0.5 & 1 & 1.5 & 2\end{array}$

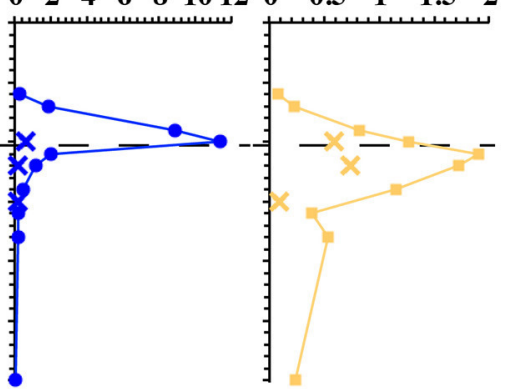

FIGURE 5 | (A) Phylogenetic tree of the nirK/aniA gene encoding a NO producing nitrite reductase containing copper. Names with ETNP indicate sequences assembled from our metagenomes. Labels colors on the tree match individual OTU depth profiles below (C-G). Depth profiles of (B) total nirK and nirK phylotypes: (C) OTU I, (D) OTU II, (E) Chloroflexi (F) ammonia-oxidizing archaea, (G) nitrite oxidizer Nitrospina. In all depth profiles, Xs indicate particulate (>30 $\mu \mathrm{m})$ samples. Dashed line represents the top of the ODZ. \% Community is calculated in comparison to the single copy core gene RNA polymerase (rpoB). Red asterisks indicate placement of ETNP transcripts from Ganesh et al. (2015). 


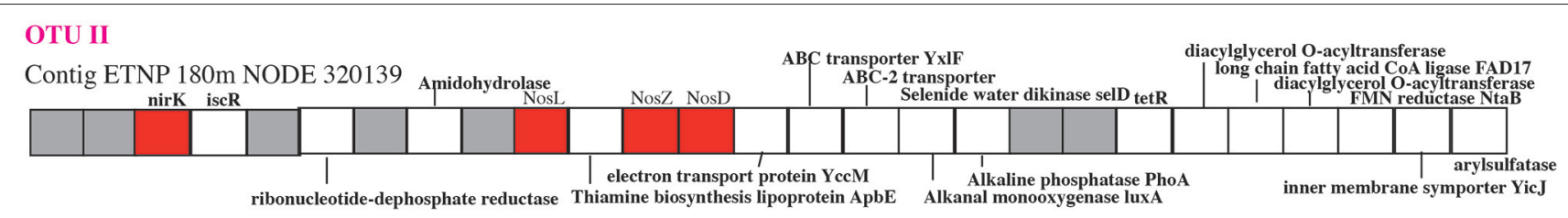

FIGURE 6 | Schematic of a contig containing a nirK gene and a nos $Z$ gene. Hypothetical proteins are shown in gray and genes of interest are in red. NosL is a copper chaperone and NosD is part of a copper transporter.

our OTU III (Figure S10). In our dataset, however, there is no correlation between any qnorB-like gene OTUs and subunits of methane mono-oxygenase, pmoA, and pmoB. NC10 pmoA was possessed by at most of $0.1 \%$ of the community, and pmoB was barely above detection and no $\mathrm{NC10} p m o B$ was detectable in our metagenomes. In contrast, the qnorB-like gene was present in $>25 \%$ of the community in particles (Figure 3). Thus, the large difference in \% community between gene in these two pathways makes it seems unlikely that the abundant organisms containing the qnorB-like gene are involved in methane oxidation. Additionally, when our long contigs containing qnorB-like gene are examined, none of the contigs had BLAST hits in National Center for Biotechnology Information (NCBI) nucleotide collection database (nt) (NCBI Resource Coordinators, 2017) with E values $<-20$. Contig $120 \mathrm{~m}$ particle NODE 148559 has competence genes right next to the qnorB-like gene, implying that qnorB-like gene could have been transferred (Figure S11), and in general, the contigs appear to be dissimilar to each other, even between multiple contigs in the same qnorB-like phylotype (OTU II; Figure S11). Thus, the qnorB-like gene appears to be in multiple organisms in the ETNP, which are not related to Cand. Methylomirabilis or other bacteria in the NCBI nucleotide database.

\section{$\mathrm{N}_{2}$ Gas Production}

The final step in denitrification, $\mathrm{N}_{2}$ production from $\mathrm{N}_{2} \mathrm{O}$, is mediated by nos $Z$, which was elevated from 90 to $140 \mathrm{~m}$ (Figure 1G). The nos $Z$ gene depth profile had two maxima at 100 and $140 \mathrm{~m}$ (Figure 1), which corresponded to the two $\mathrm{N}_{2} \mathrm{O}$ concentration maxima in the lower oxycline and at $140 \mathrm{~m}$. Potential $\mathrm{N}_{2} \mathrm{O}$ reduction rates also had a maximum at $140 \mathrm{~m}$ (2.7 nM/d, Babbin et al., 2015). The $\mathrm{N}_{2} \mathrm{O}$ reductase gene nos $Z$ had 5 phylotypes in the ETNP. Notably these ETNP nos $Z$ phylotypes were completely different from sequences from the coastal ETSP (Castro-González et al., 2015) (Figure 8A). ETNP $\mathrm{N}_{2} \mathrm{O}$ reductase (nosZ) phylotypes could be separated into two groups based on their depth distribution with maxima corresponding to the two $\mathrm{N}_{2} \mathrm{O}$ concentration maxima (Figure 8). It is possible that these different depth profiles represent different tolerances of the organisms to oxygen. The Flavobacterial nos $Z$ was abundant at the top of the ODZ with a maximum at $100 \mathrm{~m}$, corresponding to the upper nos $Z$ gene maxima (Figure 8B). This group is represented by one extensive 11 gene contig (ETNP $120 \mathrm{~m}$ NODE 73975) containing nosD, nosZ, and cytochrome $\mathrm{c}$ (Figure S12). The best BLAST hit for this contig was the Flavobacteria Lutibacter sp. LPI (\#CP013355), confirming the Flavobacteria affinity of this nos $Z$. The other 4 phylotypes represent novel clades. One clade of nos $Z$ sequences clustered with Chloroflexi, but this clade was not represented by multi-gene contigs. The Flavobacteria and potential Chloroflexi phylotypes both had their maxima at the upper $\mathrm{N}_{2} \mathrm{O}$ peak and made up roughly similar \% community in the water and on particles (Figures 8B,C, Figure S13). The other three unidentified phylotypes each had maxima at the second $\mathrm{N}_{2} \mathrm{O}$ maximum at $140 \mathrm{~m}$ (Figures 8D-F). One of the nosZ phylotypes had the C terminal extension typical of $S$ oxidizing bacteria, suggesting it may belong to an autotrophic denitrifier, and this phylotype was enriched in particles (Figures 8A,F, Figure S13). This clade was represented by a contig containing 23 gene sequences (ETNP $120 \mathrm{~m}$ NODE 137405) including a photosystem I gene psaC along with nosL, nosD, and nosZ (Figure S12). The fourth nos $Z$ phylotype, OTU I, was predominately free-living (Figure 8D, Figure S13). This phylotype was represented by three extensive contigs (Figure S12). Multiple genes on the contigs identified this organism as a heterotroph, including beta-galactosidase. Particles were dominated by the fifth nosZ phylotype, OTU II (Figure 8E, Figure S13). Two extensive contigs represent the upper branch of OTU II (Figure S12). Along with genes for nosL, nosD, and nosZ, contig ETNP $180 \mathrm{~m}$ NODE 320139 also contained a nirK gene belonging to nirK OTU II, a phylotype that was also particle attached. Thus, nosZ phylotype OTU II and nirK OTU II are both the same unidentified organism (Figure 6).

Genes representing the second $\mathrm{N}_{2}$ producing pathway, anammox, had a maximum from 120 to $180 \mathrm{~m}$ (Figures 2D,G, 9A). Notably the depth profile of the gene for hydrazine oxidoreductase ( $h z o$ ), the final step in the anammox pathway, was consistent with both the nirS and $r p o B$ reads that branched with Cand. Scalindua (Figure 9A). As expected, only one phylotype of anammox bacteria was present on both $h z o$ and nirS phylogenetic trees (Figures S9, S14). The combined maxima in anammox genes and nos $Z$ corresponded to the upper $\mathrm{N}_{2}$ gas maximum (Figure $1 \mathrm{H}$ ). This depth profile for anammox genes is consistent with intact ladderane lipid data from the same station (Sollai et al., 2015) and with calculated anammox rates (Figure 9A). Anammox rates were estimated by subtracting $\mathrm{N}_{2} \mathrm{O}$ reduction rates (Babbin et al., 2015) from total $\mathrm{N}_{2}$ production rates from $\mathrm{BB} 2$ (Babbin et al., 2014) and these differential rates showed some variability, but still had a maximum at the same depth as the metagenomic reads (Figure 9A). 


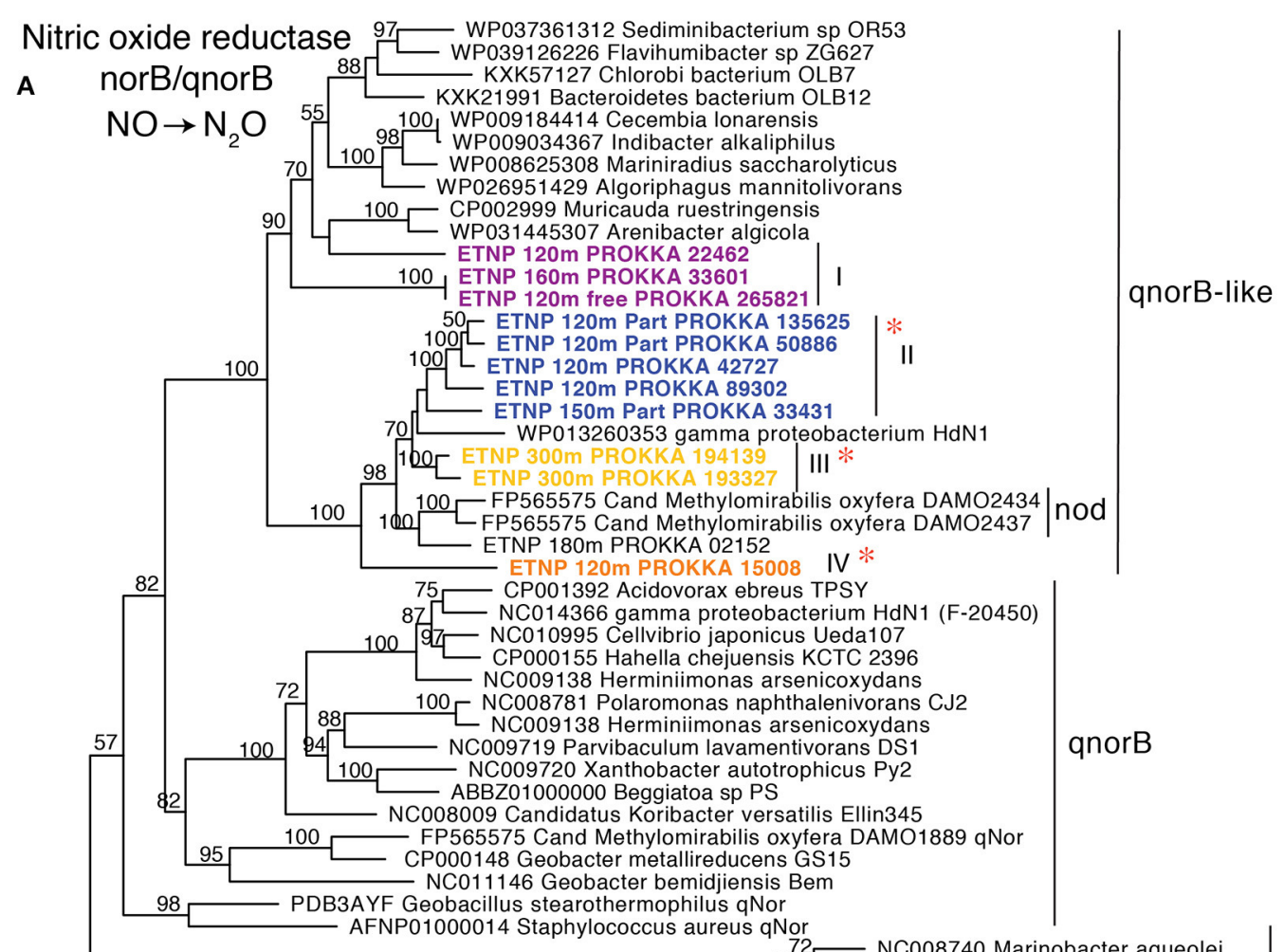
NC008740 Marinobacter aqueolei $99-$ CP000083 Colwellia psychreryth

$94-71-$ CP000083 Hahella chejuensis 74 - AP010552 Cand Thioglobus autotrophica 81 NC016002 Pseudogulbenkiania sp NH8B 100 NC016002 Pseudogubenkania sp N NC014366 gamma HdN1 (F-37100)

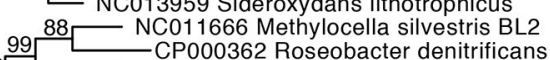
100 NC007626 Magnetospirillum magneticum AMB NC008340 Alkalilimnicola ehrlichei MLHE1

0.5

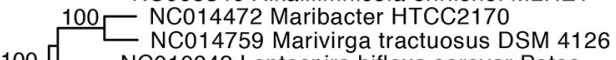

100 NC010842 Leptospira biflexa serovar Patoc

80 _ ETNP $100 \mathrm{~m}$ Part PROKKA 110046

100 NC005363 Bdellovibrio bacteriovorus 70 NC016112 Methylomicrobium alcaliphilum NC002977 Methylococcus capsulatus

59 - ETNP $120 \mathrm{~m}$ PROKKA 317121

$100 \quad 100 \square$ AP009179 Sulfurovum sp NBC37

AFRZ01000001 Sulfurimonas gotlandica NC014761 Oceanithermus profundus 506 NC010794 Methylacidiphilum infernorum V4

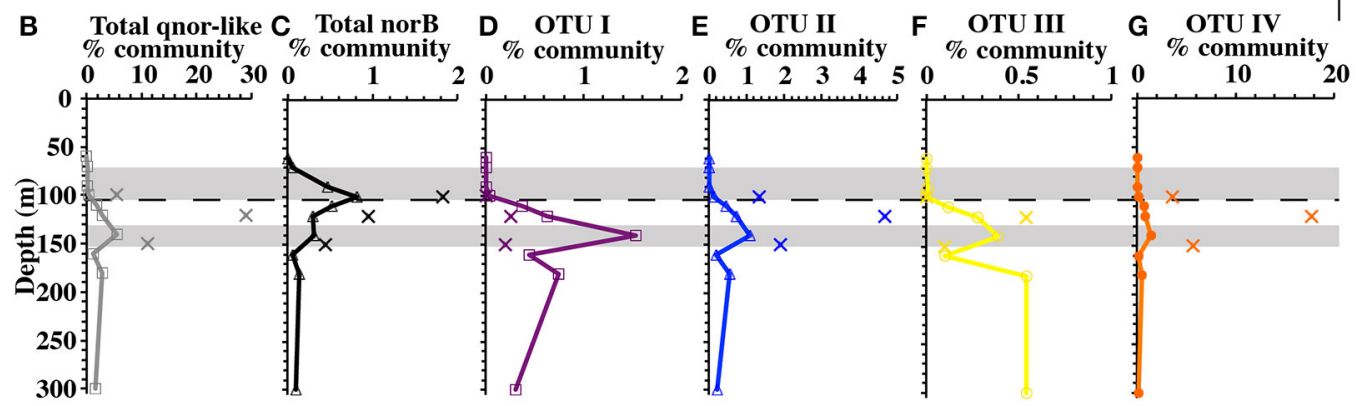

FIGURE 7 | (A) Phylogenetic tree of nitric oxide reducing enzymes norB, qnorB, and q-norB-like. Putative nod genes are indicated. Names with ETNP indicate sequences assembled from our metagenomes. Labels and colors on the tree match individual depth profiles (D-G). Depth profiles of (B) total qnorB-like, and (C) total norB sequences as well as q-norB-like phylotypes: (D) OTU I, (E) OTU II, (F) OTU III, and (G) OTU IV. In all depth profiles, Xs indicate particulate (>30 $\mu \mathrm{m}$ ) samples. Shaded area indicates the depth of the $\mathrm{N}_{2} \mathrm{O}$ maxima (Figure 1). Dashed line represents the top of the ODZ. \% Community is calculated in comparison to the single copy core gene RNA polymerase (rpoB). Red asterisks indicate placement of ETNP transcripts from Ganesh et al. (2015). 

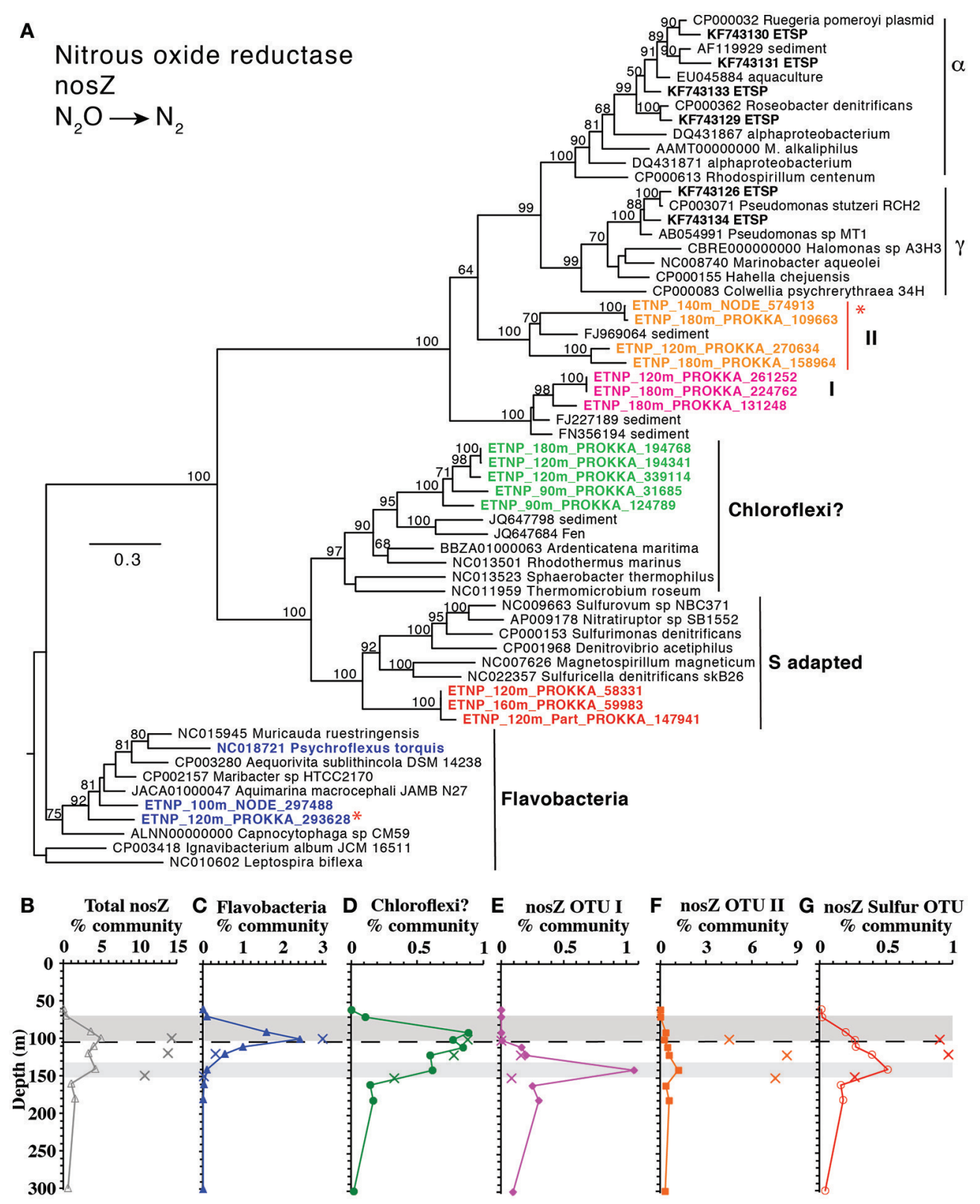

FIGURE 8 | (A) Phylogenetic tree of $\mathrm{N}_{2} \mathrm{O}$ reductase enzyme nosZ. Names with ETNP indicate full-length sequences assembled from our metagenomic samples. Colors on the tree match individual OTU depth profiles (C-G). Depth profiles of (B) total nosZ and of nosZ phylotypes: (C) Flavobacteria, (D) Chloroflexi, (E) OTU I, (F) OTU II, and (G) Sulfur adapted. In all depth profiles, Xs indicate particulate (>30 $\mu \mathrm{m}$ ) samples. Shading on depth profiles indicates depth of the two $\mathrm{N}_{2} \mathrm{O}$ maxima (Figure 1). Dashed line represents the top of the ODZ. \% Community is calculated in comparison to the single copy core gene RNA polymerase (rpoB). Red asterisks indicate placement of ETNP transcripts from Ganesh et al. (2015).

\section{Correlation of Functional Gene Abundance with Activity}

Although gene presence assessed by metagenomics only confirms the potential for a given function, the anammox data suggest a close correspondence in space between the presence of an organism and its activity in this environment. We further assessed this relationship in two other well-characterized microbial groups, the ammonia-oxidizing MGI Thaumarchaeota, and the nitrite oxidizer Nitrospina. The depth profile of the ammonia monooxygenase gene amoA was tightly correlated with MGI Thaumarchaeota specific nirK and $r p o B$ reads, and all three genes had a maximum at $100 \mathrm{~m}$ (Figure 9B). Previously determined qPCR measurements of $a m o A$ at BB2 also had a maximum at $100 \mathrm{~m}$ (Peng et al., 2015), and the overall depth profiles were consistent with a slope of 1106.2 cells per $\mathrm{mL} / \%$ community with amoA $\left(R^{2}=0.7\right)$. Rates of ammonia oxidation, which were calculated including ammonia oxidized to both nitrite and nitrate (Peng et al., 2015) had a maximum at 

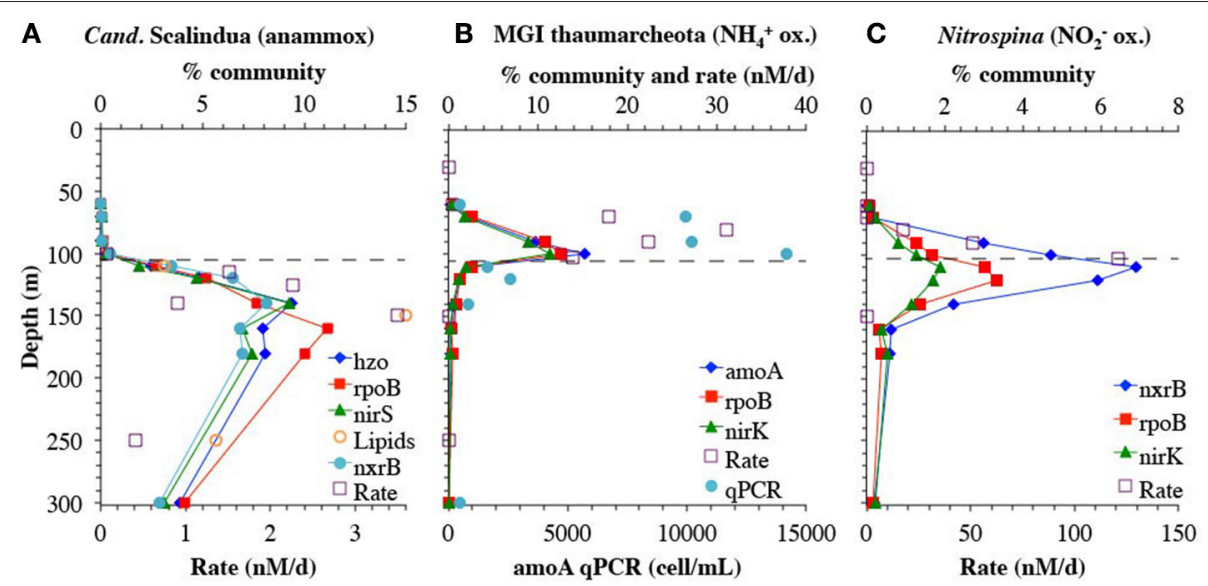

FIGURE 9 | A comparison between genes and rates. (A) Genes for anammox bacteria Cand. Scalindua for nitrite reductase (nirS), hydrazine oxidoreductase (hzo) and single copy core gene rpoB. Anammox rates are calculated by subtracting $\mathrm{N}_{2} \mathrm{O}$ reduction rates (Babbin et al., 2015) from total $\mathrm{N}_{2}$ production rates from $\mathrm{BB} 2$ (Babbin et al., 2014). PC-monoether ladderane lipid values are from St 136 in Sollai et al. (2015), but are normalized to fit on the \% community axis; values are 15 pg/L at $110 \mathrm{~m}, 72 \mathrm{pg} / \mathrm{L}$ at $150 \mathrm{~m}, 27 \mathrm{pg} / \mathrm{L}$ at $250 \mathrm{~m}$, and $25 \mathrm{pg} / \mathrm{L}$ at $350 \mathrm{~m}$. (B) genes for ammonia oxidizing MGI Thaumarcheota for ammonia monooxygenase (amoA), nitrite reductase (nirK), and single copy core gene rpoB. Ammonia oxidizing rates and amoA qPCR are from BB2 in Peng et al. (2015). (C) genes from nitrite oxidizing bacterium Nitrospina for nitrite reductase (nirK), nitrite oxidoreductase ( $n x r B)$, and single copy core gene rpoB. Nitrite oxidizing rates are from BB2 in Peng et al. (2015). Dashed line represents the top of the ODZ. \% Community is calculated in comparison to the single copy core gene RNA polymerase (rpoB).

$80 \mathrm{~m}$, above the maxima in both qPCR and metagenomic reads (Figure 9B).

The gene encoding the nitrite oxidizing enzyme nitrite oxidoreductase $(n \times r B)$ had a maximum in the ODZ at $110 \mathrm{~m}$, again consistent with Nitrospina specific nirK and rpoB reads. Unlike in the Arabian Sea (Lüke et al., 2016), here nitrite oxidoreductase can be solely attributed to Nitrospina (Figure 9C, Figure S6). Like isolate Nitrospina gracilis (Lücker et al., 2013), it appears that the ODZ Nitrospina has two copies of the $n \times r B$ gene per genome, as determined by comparison with the single copy core gene $r p o B$ (Figure 9C). This genetic potential for nitrite oxidation within the $\mathrm{ODZ}$ is consistent with measured nitrite oxidation rates of $>100 \mathrm{nM} / \mathrm{d}$ at BB2 (Figure 9C) (Peng et al., 2015) and nitrite oxidation rates had a similar depth profile as the metagenomic read depth profile for Nitrospina. Nitrite oxidizers in the ETSP had a high affinity for oxygen with a low oxygen $\mathrm{K}_{\mathrm{m}}$ of $0.5 \pm 4.0 \mathrm{nM}$ (Bristow et al., 2016). It has been suggested that oxygen production by Prochlorococcus in the ODZ can fuel nitrite oxidation (Garcia-Robledo et al., 2017).

The three examples above, Cand. Scalindua, MGI Thaumarchaeota, and Nitrospina, demonstrate that the read placement technique produces consistent results when applied to multiple genes in the same organism, supporting the use of normalized read placement as a semi quantitative method to examine microbial depth profiles. This approach is also valuable for understanding distributions of as yet uncharacterized organisms. For example, previously, the phylogeny of metagenomic and metatranscriptomic reads in ODZs have been identified with BLAST using the NCBI nucleotide collection database (nt/nr) (Ganesh et al., 2014, 2015; Glass et al., 2015). When re-examining this previous data with our read placement approach that incorporates the corresponding metagenome assemblies on the reference tree, we find the same functional gene identification (narG, nirK etc) as found with BLAST, but the phylogenetic affiliation of each gene can be better determined. BLAST identifications depend greatly on the composition of the database (Fuchsman and Rocap, 2006), and is a determination via local alignment. The placement approach can provide a higher resolution determination among closely related organisms in part because the whole sequence is used for comparison to a known reference (Berger et al., 2011). For example, using BLAST against NCBI nt/nr database, the phylogenetic identity of nitric oxide reductase transcripts from the coastal ETNP in 2013 was highly variable with depth (Ganesh et al., 2015). However, here these transcripts consistently place on three uncultured ETNP qnor-like OTUs assembled from our metagenome, which were not present in the original NCBI nt/nr BLAST database (Figure 7). Similarly, the identity of $\mathrm{N}_{2} \mathrm{O}$ reductase nos $Z$ transcripts from this same ETNP metatranscriptome were reported as predominantly unknown prokaryote (Ganesh et al., 2015). Read placement of those transcripts on a phylogenetic tree indicates that the unknown prokaryote transcripts are all OTU II (Figure 8), which can now be linked to other $\mathrm{N}$ cycling genes (Figure 6) through our assembly and to a particleattached lifestyle (Figure 8). Thus, read placement techniques in combination with assemblies from the relevant environment allow us to take the next step in understanding the community in ODZs.

\section{$\mathrm{N}_{2} \mathrm{O}$ and $\mathrm{N}_{2}$ Production in the Oxycline}

We apply this holistic approach to analysis of $\mathrm{N}$ cycling genes with chemical measurements and rate data to the oxycline above the ETNP ODZ, which has been implicated as a potential source of $\mathrm{N}_{2} \mathrm{O}$, a potent greenhouse gas, to the atmosphere (Cohen and Gordon, 1978; Yamagishi et al., 2007; Babbin et al., 2015). 
Here, concentrations of $\mathrm{N}_{2} \mathrm{O}$ were highest $(106 \mathrm{nM})$ at $90 \mathrm{~m}$ within the oxycline (Figure 1F, Peng et al., 2015). In addition to production by nitric oxide reductases during denitrification, $\mathrm{N}_{2} \mathrm{O}$ is also produced by ammonia oxidizing archaea (Santoro et al., 2011). The enzymes involved in this process are unclear and the last step of $\mathrm{N}_{2} \mathrm{O}$ production may be non-enzymatic in archaea (Kozlowski et al., 2016). From isotopomer analysis of $\mathrm{N}_{2} \mathrm{O}$ in the upper ETNP oxycline, ammonia oxidizers contribute more than denitrifiers to $\mathrm{N}_{2} \mathrm{O}$ production, but in the lower oxycline both processes may be present (Yamagishi et al., 2007). Indeed, in the ETSP incubation experiments indicated that both ammonia oxidation and denitrification contributed to $\mathrm{N}_{2} \mathrm{O}$ production in the lower oxycline (Ji et al., 2015). Here, at station BB2, ammonia oxidation rates, which were solely attributed to archaea, were measurable throughout the oxycline, corresponding with the $\mathrm{N}_{2} \mathrm{O}$ maximum, and were still $13 \mathrm{nM} / \mathrm{d}$ at $103 \mathrm{~m}$ (Peng et al., 2015). This is consistent with our metagenomic data indicating MGI Thaumarchaeota made up to $12 \%$ of the community at $100 \mathrm{~m}$, corresponding to the upper $\mathrm{N}_{2} \mathrm{O}$ maximum (Figures 2E,F, 5). However, if ammoniaoxidizing archaea were the only source of $\mathrm{N}_{2} \mathrm{O}$ here, the byproduct $\mathrm{N}_{2} \mathrm{O}$ would be $\sim 20 \%$ of oxidized ammonia in the oxycline at BB2 (Peng et al., 2015). $\mathrm{N}_{2} \mathrm{O}$ yields of marine archaea under normal oxygen conditions are $<1 \%$ (Santoro et al., 2011; Loscher et al., 2012) though yields up to $1.6 \%$ were found in the oxycline of the ETSP (Ji et al., 2015). Thus, some form of denitrification in the lower oxycline $(90-100 \mathrm{~m})$ is necessary to explain the $\mathrm{N}_{2} \mathrm{O}$ measurements (Babbin et al., 2015; Peng et al., 2015). However, here no nitric oxide reductases (either norB or qnorB-like) were detected in the water column at $90 \mathrm{~m}$ and nor $B$ was only present in $1 \%$ of the community at $100 \mathrm{~m}$ in our whole water samples (Figure 1). We suggest production of $\mathrm{N}_{2} \mathrm{O}$ inside particles can explain these $\mathrm{N}_{2} \mathrm{O}$ measurements. Although qnorB-like nitric oxide reductase was not detected in the water column in the oxycline at station 136, it was present in particles (5.5\% of the particle community) at the base of the oxycline $(100 \mathrm{~m})$ at station BB2 and norB was also present (2.2\% of the particle community) (Figure S8). Thus, particle communities in the oxycline have the capacity to produce $\mathrm{N}_{2} \mathrm{O}$. This is understandable as there are oxygen gradients inside marine organic particles (Ploug et al., 1997), and measurements of diatom aggregates indicate that at $\sim 100 \mu \mathrm{mol} \mathrm{L}^{-1}$ ambient $\mathrm{O}_{2}$ and below aggregates contained anoxic regions from which $\mathrm{N}_{2} \mathrm{O}$ and $\mathrm{N}_{2}$ production could be measured (Stief et al., 2016). Zooplankton carcasses may also be sites of denitrification below $\sim 10 \mu \mathrm{mol} \mathrm{L}^{-1}$ ambient $\mathrm{O}_{2}$ (Stief et al., 2017). Thus, based on the measured STOX oxygen concentrations ( 4.7 and $0.8 \mu \mathrm{M}$ at 90 and $100 \mathrm{~m}$ ) the majority of particles should contain anoxic zones in the ETNP lower oxycline. $\mathrm{N}_{2} \mathrm{O}$ production from sediment trap material under oxic conditions has been shown previously in the North Pacific (Wilson et al., 2014).

$\mathrm{N}_{2} \mathrm{O}$ is also potentially consumed in the lower oxycline, forming $\mathrm{N}_{2}$. Although denitrification can be $50 \%$ inhibited by $200-300 \mathrm{nM} \mathrm{O}_{2}$ (Dalsgaard et al., 2014), $\mathrm{N}_{2}$ production in the oxycline is consistent with the $\mathrm{N}_{2}$ gas concentration profile (Figure $1 \mathrm{H}$ ). Potential $\mathrm{N}_{2} \mathrm{O}$ reduction rates extend into the oxycline $(1 \mathrm{nM} / \mathrm{d}$ at $85 \mathrm{~m})$, though vials for these rates were incubated anaerobically (Babbin et al., 2015). Importantly, measured gas in the water column, either $\mathrm{N}_{2} \mathrm{O}$ or $\mathrm{N}_{2}$, represents both water column and particulate production. As with $\mathrm{N}_{2} \mathrm{O}$ production, particles may also be important for $\mathrm{N}_{2}$ production in the oxycline. $\mathrm{N}_{2} \mathrm{O}$ reductase (nos $Z$ ) was found in $3-5 \%$ community in bulk water in the oxycline at station 136 (Figure 1G), and only two phylotypes were present (Flavobacteria and Chloroflexi) (Figures 8B,C). This suggests that all denitrifiers may not have the same oxygen inhibition threshold or that Flavobacteria and Chloroflexi are facultative denitrifiers. Notably, nos $Z$ was also enriched in the $100 \mathrm{~m}$ particles at station $\mathrm{BB} 2$ where it was contained by $13 \%$ of the community (Figure S8) represented by nos $Z$ OTU II and Flavobacteria nosZ (Figure 8). Thus, much of the $\mathrm{N}_{2}$ gas production in the oxycline may occur on particles.

\section{Niche Partitioning}

Microbes containing $\mathrm{N}$ cycling genes examined here separate into three groups with distinct niches: particle-attached, freeliving with tolerance to low levels of oxygen, free-living with preference to complete anoxia. Genes in bacteria attached to particles could either be taking advantage of the abundant organic matter there or of the more reduced conditions found inside particles. It appears that three phylotypes of narG, one phylotype of nirK, two phylotype of nirS, two phylotype of qnor-like and two phylotype of nos $Z$ genes are particle attached, including the nos $Z$ affiliated with S-oxidizers (Figures 4, 5, 7, 8, Figures S9, S13). In the water column, genes can be separated into two niches based on oxygen content. Genes found in the upper ODZ are likely exposed to nanomolar oxygen either by mixing or by $\mathrm{O}_{2}$ production by ODZ Prochlorococcus (GarciaRobledo et al., 2017). Some OTUs appear to be tolerant of oxygen while others are only abundant below $120 \mathrm{~m}$ after all possible $\mathrm{O}_{2}$ has been removed. Genes from oxygen utilizing microbes, ammonia oxidizing archaea and nitrite oxidizing bacteria were found in the upper ODZ (Figure 9). Genes for anammox bacteria were abundant below $120 \mathrm{~m}$ (Figure 9), which could imply a lack of tolerance to oxygen or competition with ammonia and nitrite oxidizers for its reactant ammonium (Penn et al., 2016). All of the nirK phylotypes that are enriched in bulk water are found in the upper ODZ while all the nirS OTUs are abundant below $120 \mathrm{~m}$ (Figure 5, Figure S9), implying different oxygen tolerances for bacteria with these genes. Additionally, all the qnor-like genes were abundant below $120 \mathrm{~m}$ (Figure 7). Two water column nos $Z$ phylotypes were found in the upper ODZ while one free-living nos $Z$ was abundant below $120 \mathrm{~m}$ (Figure 8, Figure S13), indicating diversity of oxygen tolerance between types of denitrifiers. The free-living SAR11 narG phylotypes were abundant throughout the ODZ, but not in the oxycline, so did not clearly fall into our defined water-column niches (Figure 4 , Figure S13). Due to their differing depth profiles and niches, it is possible that not all these free-living microbes have all the genes necessary to perform complete denitrification. In all, these data highlight the diversity of $\mathrm{N}$ reducing microbes in the ODZ. 


\section{Synthesis}

Here we describe gene abundances and distinct phylotypes for all key steps in the low oxygen $\mathrm{N}$ cycle in an openocean ODZ community. Although gene presence only indicates potential activity, relative gene abundances here correlated closely with features in chemical profiles and measured rates for denitrification, anammox, ammonia oxidation, and nitrite oxidation (Babbin et al., 2014, 2015; Peng et al., 2015). Both anammox and $\mathrm{N}_{2}$ producing denitrifiers were present in the water column with denitrifiers found at shallower depths, reaching the oxycline. Overall, denitrification genes, with the exception of nitrate reductase, were enriched in $>30 \mu \mathrm{m}$ particles. However, when examined at a phylotype level, two $\mathrm{N}_{2} \mathrm{O}$ reductase phylotypes were enriched on particles while three other nos $Z$ phylotypes were actually not enriched in particles. Furthermore, Flavobacteria and Chloroflexi nos $Z$ phylotypes had maxima within lower oxycline, while the remaining nos $Z$ phylotypes had maxima within the ODZ. These data highlight the diversity of denitrifiers both phylogenetically and potentially functionally.

While we did not find evidence for denitrification without an $\mathrm{N}_{2} \mathrm{O}$ intermediate by autotrophic methane-oxidizers, autotrophic denitrification is still a distinct probability in the ETNP. The presence of a C-terminal extension on nosZ in a group of assembled contigs indicated the presence of a S-oxidizing autotrophic denitrifying phylotype on particles. A S-oxidizing autotrophic denitrifier was previously found on particles in the suboxic zone of the Black Sea (Fuchsman et al., 2012a). These data support the possibility of low level but widespread S cycling in particles under low oxygen conditions.

The largest $\mathrm{N}_{2} \mathrm{O}$ maxima in the ETNP are in the oxycline above the ODZ. Since ammonia oxidation rates are too low to support all the $\mathrm{N}_{2} \mathrm{O}$ production in the oxycline (Peng et al., 2015),

\section{REFERENCES}

Altschul, S. F., Madden, T. L., Schäffer, A. A., Zhang, J., Zhang, Z., Miller, W., et al. (1997). Gapped BLAST and PSI-BLAST: a new generation of protein database search programs. Nucleic Acids Res. 25, 3389-3402. doi: 10.1093/nar/25. 17.3389

Apweiler, R., Bairoch, A., Wu, C. H., Barker, W. C., Boeckmann, B., Ferro, S., et al. (2004). UniProt: the universal protein knowledgebase. Nucleic Acids Res. 32, D115-D119. doi: 10.1093/nar/gkh131

Babbin, A. R., Bianchi, D., Jayakumar, A., and Ward, B. B. (2015). Rapid nitrous oxide cycling in the suboxic ocean. Science 348, 1127-1129. doi: $10.1126 /$ science.aaa 8380

Babbin, A. R., Keil, R. G., Devol, A. H., and Ward, B. B. (2014). Oxygen control nitrogen loss in the ocean. Science 344:406. doi: 10.1126/science.1248364

Berger, S. A., Krompass, D., and Stamatakis, A. (2011). Performance, accuracy, and web server for evolutionary placement of short sequence reads under maximum likelihood. Syst. Biol. 60, 291-302. doi: 10.1093/sysbio/syr010

Berger, S. A., and Stamatakis, A. (2011). Aligning short reads to reference alignments and trees. Bioinformatics 27, 2068-2075. doi: 10.1093/bioinformatics/btr320

Bolger, A. M., Lohse, M., and Usadel, B. (2014). Trimmomatic: a flexible trimmer for Illumina sequence data. Bioinformatics 30, 2114-2120. doi: 10.1093/bioinformatics/btu170

Bowen, J. L., Weisman, D., Yasuda, M., Jayakumar, A., Morrison, H. G., and Ward, B. B. (2015). Marine oxygen-deficient zones harbor depauperate denitrifying an additional source of $\mathrm{N}_{2} \mathrm{O}$ production is likely (Babbin et al., 2015). Our metagenomic data supports production of $\mathrm{N}_{2} \mathrm{O}$ inside particles in the oxycline, rather than denitrification in the water column.

In a warming ocean with lower oxygen concentrations, the area of both ODZs and the oxycline above them may expand. Understanding the diversity and function of water column and particle associated communities in these regions may be critical for correctly predicting the magnitude of $\mathrm{N}$ loss and $\mathrm{N}_{2} \mathrm{O}$ release to the atmosphere.

\section{AUTHOR CONTRIBUTIONS}

CF: collected the samples, created metagenomic libraries, designed, and performed analyses and wrote the paper; JS: wrote code essential to the analyses and edited the paper; CM: assembled the metagenomes, wrote code used in analyses, and edited the paper; AD and GR: helped design analyses and edited the paper.

\section{ACKNOWLEDGMENTS}

We thank William Brazelton for helpful discussions. Captain and crew of the R/V Thompson. Bonnie X. Chang for OPA ammonia data. Aaron Morello for shipboard nutrient analyses. This study was funded by NSF grants to AD. OCE-1029316 and to GR. OCE-1138368.

\section{SUPPLEMENTARY MATERIAL}

The Supplementary Material for this article can be found online at: https://www.frontiersin.org/articles/10.3389/fmicb. 2017.02384/full\#supplementary-material

communities compared to novel genetic diversity in coastal sediments. Microb. Ecol. 70, 311-321. doi: 10.1007/s00248-015-0582-y

Bristow, L. A., Dalsgaard, T., Tiano, L., Mills, D. B., Bertagnolli, A. D., Wright, J. J., et al. (2016). Ammonium and nitrite oxidation at nanomolar oxygen concentrations in oxygen minimum zone waters. Proc. Natl. Acad. Sci. U.S.A. 113, 10601-10606. doi: 10.1073/pnas.1600359113

Brown, C. T., Howe, A., Zhang, Q., Pyrkosz, A. B., and Brom, T. H. (2012). A reference-free algorithm for computational normalization of shotgun sequencing data. arXiv:1203.4802v2.

Canfield, D. E., Stewart, F. J., Thamdrup, B., De Brabandere, L., Dalsgaard, T., DeLong, E. F., et al. (2010). A cryptic sulfur cycle in oxygen-minimum-zone waters off the chilean coast. Science. 330:1375. doi: 10.1126/science.1196889

Castro-González, M., Ulloa, O., and Farías, L. (2015). Structure of denitrifying communities reducing $\mathrm{N} 2 \mathrm{O}$ at suboxic waters off northern Chile and Perú. Rev. Biol. Mar. Oceanogr. 50, 95-110. doi: 10.4067/S0718-19572015000100008

Chang, B. X., Devol, A. H., and Emerson, S. R. (2010). Denitrification and the nitrogen gas excess in the eastern tropical South Pacific oxygen deficient zone. Deep Sea Res. Part I Oceanogr. Res. Pap. 57, 1092-1101. doi: 10.1016/j.dsr.2010.05.009

Chang, B. X., Devol, A. H., and Emerson, S. R. (2012). Fixed nitrogen loss from the eastern tropical North Pacific and Arabian Sea oxygen deficient zones determined from measurements of N 2 :Ar. Global Biogeochem. Cycles 26:GB004207. doi: 10.1029/2011GB004207

Chang, B. X., Rich, J. R., Jayakumar, A., Naik, H., Pratihary, A. K., Keil, R. G., et al. (2014). The effect of organic carbon on fixed nitrogen loss in the eastern tropical 
South Pacific and Arabian Sea oxygen deficient zones. Limnol. Oceanogr. 59, 1267-1274. doi: 10.4319/lo.2014.59.4.1267

Clegg, S. L., and Whitfield, M. (1990). A generalized model for the scavenging of trace metals in the open ocean-I. Particle cycling. Deep Sea Res. Part A. Oceanogr. Res. Pap. 37, 809-832. doi: 10.1016/0198-0149(90)90008-J

Cohen, Y., and Gordon, L. (1978). Nitrous oxide in the oxygen minimum of eastern tropical North Pacific: evidence for its consumption during denitrification and possble mechanisms for its production. Deep Sea Res. 25, 509-524. doi: 10.1016/0146-6291(78)90640-9

Crusoe, M. R., Alameldin, H. F., Awad, S., Boucher, E., Caldwell, A., Cartwright, R., et al. (2015). The khmer software package: enabling efficient nucleotide sequence analysis. F1000Res. 4:900. doi: 10.12688/f1000research.6924.1

Dalsgaard, T., Stewart, F. J., Thamdrup, B., De Brabandere, L., Revsbech, P., and Ulloa, O. (2014). Oxygen at nanomolar levels reversibly suppresses process rates and gene expression in anammox and denitrification in the oxygen minimum zone off Northern Chile. MBio 5, e01966-e01914. doi: 10.1128/mBio.01966-14

Dalsgaard, T., Thamdrup, B., Farías, L., and Peter Revsbech, N. (2012). Anammox and denitrification in the oxygen minimum zone of the eastern South Pacific. Limnol. Oceanogr. 57, 1331-1346. doi: 10.4319/lo.2012.57.5.1331

Delong, E. F., Franks, D. G., and Alldredge, A. L. (1993). Phylogenetic diversity of aggregate-attached marine bacterial assemblages. Limnol. Oceanogr. 38, 924-934. doi: 10.4319/lo.1993.38.5.0924

Deutsch, C., Brix, H., Ito, T., Frenzel, H., and Thompson, L. (2011). Climate-forced variability of ocean hypoxia. Science 333, 336-339. doi: $10.1126 /$ science. 1202422

Devol, A. H. (2003). Solution to a marine mystery. Nature 422:575. doi: $10.1038 / 422575 a$

DeVries, T., Deutsch, C., Rafter, P. A., and Primeau, F. (2013). Marine denitrification rates determined from a global 3-D inverse model. Biogeosciences 10, 2481-2496. doi: 10.5194/bg-10-2481-2013

Eddy, S. R. (2011). Accelerated profile HMM searches. PLoS Comput. Biol. 7:e1002195. doi: 10.1371/journal.pcbi.1002195

Edgar, R. C. (2004). MUSCLE: multiple sequence alignment with high accuracy and high throughput. Nucleic Acids Res. 32, 1792-1797. doi: $10.1093 / \mathrm{nar} / \mathrm{gkh} 340$

Ettwig, K., Butler, M., Le Paslier, D., Pelletier, E., Mangenot, S., Kuypers, M., et al. (2010). Nitrite-driven anaerobic methane oxidation by oxygenic bacteria. Nature 464:543. doi: 10.1038/nature08883

Ettwig, K. F., Speth, D. R., Reimann, J., Wu, M. L., Jetten, M. S. M., and Keltjens, J. T. (2012). Bacterial oxygen production in the dark. Front. Microbiol. 3:273. doi: $10.3389 /$ fmicb.2012.00273

Fuchsman, C. A., Kirkpatrick, J. B., Brazelton, W. J., Murray, J. W., and Staley, J. T. (2011). Metabolic strategies of free-living and aggregateassociated bacterial communities inferred from biologic and chemical profiles in the Black Sea suboxic zone. FEMS Microbiol. Ecol. 78, 586-603. doi: 10.1111/j.1574-6941.2011.01189.x

Fuchsman, C. A., Murray, J. W., and Staley, J. T. (2012a). Stimulation of autotrophic denitrification by intrusions of the Bosporus Plume into the anoxic Black Sea. Front. Microbiol. 3:257. doi: 10.3389/fmicb.2012.00257

Fuchsman, C. A., and Rocap, G. (2006). Whole-Genome reciprocal BLAST analysis reveals that planctomycetes do not share an unusually large number of genes with Eukarya and Archaea. Appl. Environ. Microbiol. 72, 6841-6844. doi: 10.1128/AEM.00429-06

Fuchsman, C. A., Staley, J. T., Oakley, B. B., Kirkpatrick, J. B., and Murray, J. W. (2012b). Free-living and aggregate-associated planctomycetes in the black sea. FEMS Microbiol. Ecol. 80, 402-416. doi: 10.1111/j.1574-6941.2012.01306.x

Ganesh, S., Bristow, L. A., Larsen, M., Sarode, N., Thamdrup, B., and Stewart, F. J. (2015). Size-fraction partitioning of community gene transcription and nitrogen metabolism in a marine oxygen minimum zone. ISME J. 9, 2682-2696. doi: 10.1038 /ismej.2015.44

Ganesh, S., Parris, D. J., DeLong, E. F., and Stewart, F. J. (2014). Metagenomic analysis of size-fractionated picoplankton in a marine oxygen minimum zone. ISME J. 8, 187-211. doi: 10.1038/ismej.2013.144

Garcia-Robledo, E., Padilla, C. C., Aldunate, M., Stewart, F. J., Ulloa, O., Paulmier, A., et al. (2017). Cryptic oxygen cycling in anoxic marine zones. Proc. Natl. Acad. Sci.U.S.A. 114, 8319-8324. doi: 10.1073/pnas.1619844114
Glass, J. B., Kretz, C. B., Ganesh, S., Ranjan, P., Seston, S. L., Buck, K. N., et al. (2015). Meta-omic signatures of microbial metal and nitrogen cycling in marine oxygen minimum zones. Front. Microbiol. 6:998. doi: 10.3389/fmicb.2015.00998

Gordon, L. I., Jennings, J. C., Ross, A. R., and Krest, J. M. (1995). A Suggested Protocol for Continuous Flow Automoated Analysis of Seawater Nutrients in the WOCE Hydrographic Program and the Hoint Global Ocean Fluxes Study. Technical Report, Oregon State University.

Haft, D. H., Selengut, J. D., Richter, R. A., Harkins, D., Basu, M. K., and Beck, E. (2013). TIGRFAMs and genome properties in 2013. Nucleic Acids Res. 41, 387-395. doi: 10.1093/nar/gks1234

Hannig, M., Lavik, G., Kuypers, M. M. M., Woebken, D., Martens-Habbena, W., and Jurgens, K. (2007). Shift from denitrification to anammox after inflow events in the central Baltic Sea. Limnol. Oceanogr. 52, 1336-1345. doi: 10.4319/lo.2007.52.4.1336

Holmes, R. M., Aminot, A., Kerouel, R., Hooker, B. A., and Peterson, B. J. (1999). A simple and precise method for measuring ammonium in marine and freshwater ecosystems. Can. J. Fish. Aquat. Sci. 56, 1801-1808. doi: 10.1139/f99-128

Hughes, M. N. (2008). Chemistry of nitric oxide and related species. Methods Enzymol. 436, 3-19. doi: 10.1016/S0076-6879(08)36001-7

Hyatt, D., Chen, G.-L., Locascio, P. F., Land, M. L., Larimer, F. W., and Hauser, L. J. (2010). Prodigal: prokaryotic gene recognition and translation initiation site identification. BMC Bioinformatics 11:119. doi: 10.1186/1471-2105-11-119

Jayakumar, A., Peng, X., and Ward, B. (2013). Community composition of bacteria involved in fixed nitrogen loss in the water column of two major oxygen minimum zones in the ocean. Aquat. Microb. Ecol. 70, 245-259. doi: 10.3354 /ame01654

Jensen, M. M., Lam, P., Revsbech, N. P., Nagel, B., Gaye, B., Jetten, M. S., et al. (2011). Intensive nitrogen loss over the Omani Shelf due to anammox coupled with dissimilatory nitrite reduction to ammonium. ISME J. 5, 1660-1670. doi: 10.1038/ismej.2011.44

Ji, Q., Babbin, A. R., Jayakumar, A., Oleynik, S., and Ward, B. B. (2015). Nitrous oxide production by nitrification and denitrification in the eastern tropical south pacific oxygen minimum zone. Geophys. Res. Lett. 42, 755-764. doi: 10.1002/2015GL066853

Jones, C. M., Stres, B., Rosenquist, M., and Hallin, S. (2008). Phylogenetic analysis of nitrite, nitric oxide, and nitrous oxide respiratory enzymes reveal a complex evolutionary history for denitrification. Mol. Biol. Evol. 25, 1955-1966. doi: 10.1093/molbev/msn146

Kalvelage, T., Lavik, G., Lam, P., Contreras, S., Arteaga, L., Löscher, C. R., et al. (2013). Nitrogen cycling driven by organic matter export in the South Pacific oxygen minimum zone. Nat. Geosci. 6, 228-234. doi: 10.1038/ngeo1739

Kampschreur, M. J., Kleerebezem, R., de Vet, W. W. J. M., and Van Loosdrecht, M. C. M. (2011). Reduced iron induced nitric oxide and nitrous oxide emission. Water Res. 45, 5945-5952. doi: 10.1016/j.watres.2011.08.056

Kozlowski, J. A., Stieglmeier, M., Schleper, C., Klotz, M. G., and Stein, L. Y. (2016). Pathways and key intermediates required for obligate aerobic ammoniadependent chemolithotrophy in bacteria and Thaumarchaeota. ISME J. 10, 1836-1845. doi: 10.1038/ismej.2016.2

Lam, P., Jensen, M. M., Kock, A., Lettmann, K. A., Plancherel, Y., Lavik, G., et al. (2011). Origin and fate of the secondary nitrite maximum in the Arabian Sea. Biogeosciences 8, 1565-1577. doi: 10.5194/bg-8-1565-2011

Lam, P., Lavik, G., Jensen, M. M., van de Vossenberg, J., Schmid, M., Woebken, D., et al. (2009). Revising the nitrogen cycle in the Peruvian oxygen minimum zone. Proc. Natl. Acad. Sci. U.S.A. 106, 4752-4757. doi: 10.1073/pnas.0812444106

Loscher, C. R., Kock, A., Konneke, M., LaRoche, J., Bange, H. W., and Schmitz, R. A. (2012). Production of oceanic nitrous oxide by ammonia-oxidizing archaea. Biogeosciences 9, 2419-2429. doi: 10.5194/bg-9-2419-2012

Lücker, S., Nowka, B., Rattei, T., Spieck, E., and Daims, H. (2013). The genome of Nitrospina gracilis illuminates the metabolism and evolution of the major marine nitrite oxidizer. Front. Microbiol. 4:27. doi: 10.3389/fmicb.2013.00027

Lüke, C., Speth, D. R., Kox, M. A. R., Villanueva, L., and Jetten, M. S. M. (2016). Metagenomic analysis of nitrogen and methane cycling in the Arabian Sea oxygen minimum zone. PeerJ. 4:e1924. doi: 10.7717/peerj.1924

Magoc, T., and Salzberg, S. (2011). FLASH: fast length adjustment of short reads to improve genome assemblies. Bioinformatics 27, 21. doi: 10.1093/bioinformatics/btr507 
NCBI Resource Coordinators (2017). Database Resources of the National Center for Biotechnology Information. Nucleic Acid Res. 4, 152. doi: 10.1093/nar/gkw1071

Orsi, W. D., Smith, J. M., Wilcox, H. M., Swalwell, J. E., Carini, P., Worden, A. Z., et al. (2015). Ecophysiology of uncultivated marine euryarchaea is linked to particulate organic matter. ISME J. 9, 1747-1763. doi: 10.1038/ismej.2014.260

Pack, M. A., Heintz, M. B., Reeburgh, W. S., Trumbore, S. E., Valentine, D. L., Xu, X., et al. (2015). Methane oxidation in the eastern tropical North Pacific Ocean water column. J. Geophys. Res. Biogeosci. 120, 1078-1092. doi: 10.1002/2014JG002900

Padilla, C. C., Bristow, L. A., Sarode, N., Garcia-robledo, E., Ramírez, E. G., Benson, C. R., et al. (2016). NC10 bacteria in marine oxygen minimum zones. ISME J. 10, 2067-2071. doi: 10.1038/ismej.2015.262

Peng, X., Fuchsman, C. A., Jayakumar, A., Oleynik, S., and Martens-habbena, W. (2015). Ammonia and nitrite oxidation in the Eastern Tropical North Pacific. Global Biogeochem. Cycles 29, 2034-2049. doi: 10.1002/2015GB005278

Penn, J., Weber, T., and Deutsch, C. (2016). Microbial functional diversity alters the structure and sensitivity of oxygen deficient zones. Geophys. Res. Lett. 43, 9773-9780. doi: 10.1002/2016GL070438

Peters, B. D., Babbin, A. R., Lettmann, K. A., Mordy, C. W., Ulloa, O., Ward, B. B., et al. (2016). Vertical modeling of the nitrogen cycle in the eastern tropical South Pacific oxygen deficient zone using highresolution concentration and isotope measurements. Global Biogeochem. Cycles 30:GB005415. doi: 10.1002/2016GB005415

Ploug, H., Grossart, H.-P., Azam, F., and Jorgensen, B. B. (1999). Photosynthesis, respiration, and carbon turnover in sinking marine snow from surface waters of Southern California Bight : implications for the carbon cycle in the ocean. Mar. Ecol. Prog. Ser. 179, 1-11. doi: 10.3354/meps179001

Ploug, H., Kiihl, M., Buchholz-cleven, B., and Jergensen, B. B. (1997). Anoxic aggregates - an ephemeral phenomenon in the pelagic environment ? Aquat. Microb. Ecol. 13, 285-294. doi: 10.3354/ame013285

Pruitt, K. D., Tatusova, T., and Maglott, D. R. (2007). NCBI reference sequences (RefSeq): a curated non-redundant sequence database of genomes, transcripts and proteins. Nucleic Acids Res. 35, 501-504. doi: 10.1093/nar/gkl842

Punta, M., Coggill, P., Eberhardt, R., Mistry, J., Tate, J., Boursnell, C., et al. (2012). The Pfam protein families databases. Nucleic Acids Res. 40, D290-D301. doi: 10.1093/nar/gkr1065

Santoro, A. E., Buchwald, C., McIlvin, M. R., and Casciotti, K. L. (2011). Isotopic signature of $\mathrm{N} 2 \mathrm{O}$ produced by marine ammonia-oxidizing archaea. Science 333, 1282-1285. doi: 10.1126/science.1208239

Saunders, J. K., and Rocap, G. (2016). Genomic potential for arsenic efflux and methylation varies among global Prochlorococcus populations. ISME J. 10, 197-209. doi: 10.1038/ismej.2015.85

Seemann, T. (2014). Prokka: rapid prokaryotic genome annotation. Bioinformatics 30, 2068-2069. doi: 10.1093/bioinformatics/btu153

Sinninghe Damsté, J. S., Strous, M., Rijpstra, W. I. C., Hopmans, E. C., Geenevasen, J. A. J., van Duin, A. C. T., et al. (2002). Linearly concatenated cyclobutane lipids form a dense bacterial membrane. Nature 419, 708-712. doi: 10.1038 /nature 01128

Sollai, M., Hopmans, E. C., Schouten, S., Keil, R. G., and Sinninghe Damsté, J. S. (2015). Intact polar lipids of Thaumarchaeota and anammox bacteria as indicators of N-cycling in the Eastern Tropical North Pacific oxygen deficient zone. Biogeosci. Discuss. 12, 4833-4864. doi: 10.5194/bgd-12-4833-2015

Spieck, E., and Bock, E. (2015). "Nitrifying bacteria," in Bergey's Manual of Systematics of Archaea and Bacteria, ed W. B. Whitman (John Wiley \& Sons, Inc.), 1-8. doi: 10.1002/9781118960608.bm00016
Stamatakis, A. (2014). RAxML version 8: a tool for phylogenetic analysis and post-analysis of large phylogenies. Bioinformatics 30, 1312-1313. doi: 10.1093/bioinformatics/btu033

Stewart, F. J., Ulloa, O., and DeLong, E. F. (2012). Microbial metatranscriptomics in a permanent marine oxygen minimum zone. Environ. Microbiol. 14, 23-40. doi: 10.1111/j.1462-2920.2010.02400.x

Stief, P., Kamp, A., Thamdrup, B., and Glud, R. N. (2016). Anaerobic nitrogen turnover by sinking diatom aggregates at varying ambient oxygen levels. Front. Microbiol. 7:98. doi: 10.3389/fmicb.2016.00098

Stief, P., Lundgaard, A. S. B., Morales-Ramírez, Á., Thamdrup, B., and Glud, R. N. (2017). Fixed-nitrogen loss associated with sinking zooplankton carcasses in a coastal oxygen minimum zone (Golfo Dulce, Costa Rica). Front. Mar. Sci. 4:152. doi: 10.3389/fmars.2017.00152

Tiano, L., Garcia-Robledo, E., Dalsgaard, T., Devol, A. H., Ward, B. B., Ulloa, O., et al. (2014). Oxygen distribution and aerobic respiration in the north and south eastern tropical Pacific oxygen minimum zones. Deep Sea Res. Part I Oceanogr. Res. Pap. 94, 173-183. doi: 10.1016/j.dsr.2014.10.001

Tsementzi, D., Wu, J., Deutsch, S., Nath, S., Rodriguez-r, L. M., Burns, A. S., et al. (2016). SAR11 bacteria linked to ocean anoxia and nitrogen loss. Nature 536, 179-183. doi: 10.1038/nature19068

van de Vossenberg, J., Woebken, D., Maalcke, W. J., Wessels, H. J., Dutilh, B. E., Kartal, B., et al. (2013). The metagenome of the marine anammox bacterium "Candidatus Scalindua profunda" illustrates the versatility of this globally important nitrogen cycle bacterium. Environ. Microbiol. 15, 1275-1289. doi: 10.1111/j.1462-2920.2012.02774.x

Ward, B. B., Devol, A. H., Rich, J. J., Chang, B. X., Bulow, S. E., Naik, H., et al. (2009). Denitrification as the dominant nitrogen loss process in the Arabian Sea. Nature 461:78. doi: 10.1038/nature08276

Wilson, S. T., del Valle, D. A., Segura-Noguera, M., and Karl, D. M. (2014). A role for nitrite in the production of nitrous oxide in the lower euphotic zone of the oligotrophic North Pacific Ocean. Deep. Res. Part I Oceanogr. Res. Pap. 85, 47-55. doi: 10.1016/j.dsr.2013.11.008

Yamagishi, H., Westley, M. B., Popp, B. N., Toyoda, S., Yoshida, N., Watanabe, S., et al. (2007). Role of nitrification and denitrification on the nitrous oxide cycle in the eastern tropical North Pacific and Gulf of California. J. Geophys. Res. Biogeosci. 112:G02015. doi: 10.1029/2006JG000227

Zerbino, D. R. (2010). Using the Velvet de novo assembler for shortread sequencing technologies. Curr. Protoc. Bioinformatics Unit-11.5, 1-13. doi: 10.1002/0471250953.bi1105s31

Zhang, Q., Awad, S., and Brown, C. (2015). Crossing the streams: a framework for streaming analysis of short DNA sequencing reads. PeerJ 3:e890v1. doi: $10.7287 /$ peerj.preprints.890v1

Zumft, W. G. (1997). Cell biology and molecular basis of denitrification. Microbiol. Mol. Biol. Rev. 61, 533-616.

Conflict of Interest Statement: The authors declare that the research was conducted in the absence of any commercial or financial relationships that could be construed as a potential conflict of interest.

Copyright (C) 2017 Fuchsman, Devol, Saunders, McKay and Rocap. This is an openaccess article distributed under the terms of the Creative Commons Attribution License (CC BY). The use, distribution or reproduction in other forums is permitted, provided the original author(s) or licensor are credited and that the original publication in this journal is cited, in accordance with accepted academic practice. No use, distribution or reproduction is permitted which does not comply with these terms. 